\title{
Combination therapy with Azithromycin, Pentoxifylline and Dexamethasone shows Complete Recovery in Severe COVID 19: Case Series of Patients in First and Second wave of Pandemic in India.
}

Dr Rupinder Kler ( $\nabla$ roopikler@gmail.com )

Medical Director, ASPP CENTRE OF INTEGRATIVE MEDICINE https://orcid.org/0000-0001-9529-5718

Dr Dilip Vaishnav

Department of Forensic Medicine, Post Graduate institute of medical education and research

Ms Pratiti Banerjee

Department of Neurology, Post Graduate institute of medical education and research

Dr Anirudh Mukherjee

Department of Internal Medicine, Post Graduate institute of medical education and research

\section{Case Report}

Keywords: ACE2, LDH, CRP, IL6, COVID-19, D Dimer, Azithromycin, Pentoxifylline, Dexamethasone, Ceftriaxone

Posted Date: August 11th, 2021

DOI: https://doi.org/10.21203/rs.3.rs-762889/v2

License: (c) (i) This work is licensed under a Creative Commons Attribution 4.0 International License. Read Full License 


\section{Abstract}

Background: COVID 19 infection caused by SARS-CoV2 virus is causing high mortality all over the world. This causes asymptomatic, mildly symptomatic, moderate, and severe illness. In severe illness, mortality is remarkably high as drugs are not effective enough to avert cytokine storm, stroke, myocarditis, or myocardial infarction. COVID-19 is a positive sense virus that directly enters the ACE2 cell and starts replication after encountering the host protein. Effective treatment has been limited to only mild and sometimes moderate cases but there is a high mortality in severe cases.

Case Presentation: Severe COVID-19 cases with different comorbities were assessed and treated in the first wave as well as the second wave of the pandemic in North India.. A total number of 305 patients were assessed for severity with their symptoms and abnormal blood parameters, out of which 109 patients severe patients were given the drugs and their symptoms and vitals were monitored along with therapy. In both the single SARS CoV 2 and the double mutant virus strain in the second wave. We measured their severity through their blood parameters by calculating high Neutrophil lymphocyte ratio, Platelet lymphocyte ratio after getting their complete blood count, diabetes, and other inflammatory markers like high LDH, CRP, Serum Ferritin, D Dimer, or IL 6 in critically ill patients as studied in previous studies. Hence, we designed this combination therapy drug protocol which was home based oral therapy with hundred percent recovery rate if initiated early. Wherever required oxygen therapy had also been recommended along with diet modification, low fatty acid diet and low carbohydrates for more effectivity. The combination of Azithromycin , Pentoxifylline and Dexamethasone had shown to be highly effective in controlling the inflammation and viral replication with dose modification. Intravenous Ceftriaxone was given as infusion in patients having viral Pnemonia .

Conclusions: This combination therapy of drugs has shown to decrease TLR mediated cytokine production. This therapy has shown full success in all high-risk patients especially in the elderly having comorbidities like Diabetes, heart diseases, cancer, autoimmune diseases.

\section{Introduction}

The recent outbreak of the COVID19 pandemic is caused by SARS-CoV2 virus which has affected substantial proportion of world population and has a high mortality, especially in the elderly. In the symptomatic patients, it can cause respiratory distress and hypoxemia that may require hospitalization (1). Total active cases of COVID19 in India stand at 411133 , and the case fatality rate of reported cases is $2.7 \%$ (https://www.mohfw.gov.in/). However, case fatality rates of symptomatic COVID19 cases hospitalized needing immediate care in various hospitals across India is still unknown.

Multiple risk factors associated with SARS-CoV-2 and the development of COVID-19 could contribute to the increased severity and earlier onset of acute ischemic stroke including generalized hypercoagulability, dysregulated immune response leading to cytokine-release syndrome, damage to endothelial cells leading to increased inflammation and thrombosis, dysregulation of the renin-angiotensin-aldosterone system, direct cytotoxic effect on the nervous system related to angiotensin converting enzyme-2 (ACE-2) receptor uptake of SARS-CoV-2 virus, hypoxemia related to cardiorespiratory failure and metabolic derangements. The purpose of these case series is to provide an overview of SARS-CoV-2 and the mechanisms related to the development of thrombosis that led to the morbidity and mortality associated with COVID-19, including acute ischemic stroke. Reported rates of arterial thrombosis range from $2.8 \%$ to $3.8 \%(10)$.

While numerous mechanisms of thrombosis have been proposed, there is activation of the innate immune system in response to introduction of a viral pathogen. This immuno-thrombosis is the interaction between the innate immune system and thrombosis (11). It focuses on interplay between activation of intravascular TF, innate immune cells, 
platelets, endothelial cells and releases neutrophil extracellular traps (NETs) which can activate the contact pathway of coagulation. This concept is a cornerstone for the main hypothesis underlying COVID-19-associated coagulopathy.

\section{MOLECULAR PATHOGENESIS OF THE POSITIVE SENSE VIRUSES}

Coronaviruses are positive sense RNA viruses which have a remarkably high pathogenicity and infectivity. These viruses directly translate their mRNA into proteins after they encounter host ribosomes. These positive sense RNA viral genomes can directly translate their protein into the host cell and process of replication of the virus begins in the cell. This leads to interactions between host translation factors (proteins of the host cell or ACE2 in a patient) and RNA replication at multiple levels after entry of the virus (2). The process of replication is started by the genes for RNA-dependent RNA polymerase (RdRp) that is utilized by all these positive strand viruses after infecting the host cell. The genomic RNA is translated by messenger RNA (mRNA) to produce polymerase and positive-strand RNA viruses use additional replication factors for membrane targeting, template recruitment, RNA capping, and other functions (3-5).

Internally, virus gains entry through 2 routes:

1. Direct entry: This happens when the virus directly lands on the 40S ribosome of the start AUG codon to make the protein. This helps the virus to form a new protein as soon as it encounters the host cell. After the protein is formed, the virus starts replication and with the help of other internal proteins and internal machinery the proteins get modified for further replication.

2. Indirect entry: This happens when the virus gains entry next to the start AUG codon and the viral protein and host protein combine to form a new modified protein. These modified proteins are needed for replication $(6,7)$.

Certain host ribosomal glycoproteins are loosely attached to the rough endoplasmic reticulum. These proteins create linear polymers of amino acids called polypeptides. These proteins are involved in the structural functions of the cell wall or membranes as receptors, for other molecules to bind. These are conjugated proteins having hydrophilic nature. Viruses also have glycoproteins that have an important function as it avoids the host immune system. Viral envelope with the help of glycoproteins identifies and binds to the receptors of the host proteins on the cell membrane. It fuses with the host membrane, allowing the capsid and genome of the virus to enter and infect the host. Glycation plays a key role in the viral replication and avoidance of the immune response. Glycosyl transfer can also occur to protein residues, to give 0-linked glycoproteins and N-linked glycoproteins and enzymes like glycoside hydrolases or glycosidases break glycosidic bonds. Enveloped viruses enter their host cells by a process of membrane fusion. This fusion can occur at the cell plasma membrane or within the endocytic vacuolar transport, depending upon the characteristics of the virus fusion protein. Each of these virus-host interactions are host specific, tissue specific and dynamics of infections. Each such virus-host interaction also represents a potential target for virus control. Mutations in another host gene, OLE1 (OLEic acid requiring), also block RNA replication after membrane association of $1 \mathrm{a}$, 2a polymerase, and viral RNA. OLE1 is an essential gene encoding Delta9 fatty acid desaturase, the key enzyme for converting saturated to unsaturated fatty acids. This enzyme is found in the endoplasmic reticulum of the host cell (8-10).

\section{MECHANISM OF ENTRY THROUGH ANGIOGENESIS}

Angiogenesis is the formation of microvasculature, a highly important mechanism of normal physiological events like pregnancy, menstruation, organ transplants and wound repair $(1,2)$. This mechanism is being appreciated in inflammatory processes, apart from tumor nutrition in various cancers including benign processes. Oncogenes have been implicated in inducing the expression of angiogenic factors like vascular endothelial growth factor (VEGF) $(3,4)$. 
Severe viral and bacterial infections have been known to induce increased angiogenesis in-vivo and these viral infections result in neoplasia and increased angiogenesis in part through viral-specific oncogenes. The viral infections most commonly studied with increased angiogenesis in-vivo are Papovaviruses (Simian virus 40, human papillomavirus) and Herpesviruses (Epstein-Barr virus) (5-9).

The importance of the two pathways essential for angiogenesis are VEGF and its receptor VGFR and ANG (Angiopoetin) with its receptor TIE (tyrosine kinase with immunoglobulin-like and EGF-like domains) which help in regulating both physiological and tumor angiogenesis. Hence, experimental drug inhibitors of both ANGPT2 and VEGF in some tumor models have been more effective than inhibition of a single pathway. Furthermore, combination of inhibition of VEGF and ANGPT2 may help to overcome the challenges in current anti-angiogenic therapies and particularly in viral infections like COVID-19 (39). Angiopoietin 1 and 2 regulate angiogenesis and vascular remodeling by interacting with the tyrosine kinase receptor TIE 2, and inhibition of angiogenesis has shown to be landmark in inhibiting virus induced cytokine response. The ANG 1 and ANG2 inhibitors could be potential pathway in blocking angiogenesis along with the vascular endothelial growth factor.(VEGF). ANG1 and ANG2 are peptide monoclonal antibody that inhibit binding of angiopoietin 1 and 2 to TIE 2, thus inhibiting angiogenesis.

\section{IMMUNOMODULATION OF COVID 19}

Toll like receptors(TLR) pathways play a major role for activation of innate immune system, secreting proinflammatory cytokines like interleukins(1, 6, Tumour necrosis factor and Interferons). Blocking the TLR pathway could lead to decreased secretion, thus helpful in controlling COVID 19 infection.

The coagulation cascade has been found to be activated during viral infections. Studies have shown that the activation may be part of the host defense system to limit spread of the pathogen. However, excessive activation of the coagulation cascade can be deleterious. In fact, inhibition of the tissue factor/factor VIla complex reduced mortality in a monkey model of Ebola hemorrhagic fever. Other studies have shown that incorporation of tissue factor into the envelope of herpes simplex virus increases infection of endothelial cells and mice. Furthermore, binding of factor $X$ to adenovirus serotype 5 increases the infection of hepatocytes and activation of the innate immune response to the virus. Hence Coagulation $x$ inhibitors would be helpful in reducing the innate immune response. In cellular studies it has been observed that coagulation proteases activate protease-activated receptors (PARs) and subtypes PAR1 and PAR2 modulate the immune response to viral infection. For instance, PAR1 positively regulates TLR3-dependent expression of the antiviral protein interferon $\beta$, whereas PAR2 negatively regulates expression. These studies indicate that the coagulation cascade plays multiple roles during viral infections.

\section{INFLAMMATORY MARKERS IN SEVERE COVID 19 INFECTION}

Lactate dehydrogenase (LDH) is an inflammatory marker which has been detected in nasopharyngeal secretions during viral upper respiratory infections (URI) and in the middle ear effusions of patients with otitis media $(5,6,7,8)$; Some studies have demonstrated it to be a biomarker of severity of inflammatory cellular injury during viral URI. The nasopharyngeal cellular injury can arise from a multitude of factors during viral URI; these include direct virus-induced cytopathic injury of the infected cells and participation of leukocytes such as neutrophils, macrophages, and lymphocytes in both antibody-dependent and antibody-independent cytotoxicity (10). A variety of chemokines and cytokines, specifically the acute-phase cytokines such as IL-1 $\beta$ and TNF- $\alpha$, and other soluble mediators can act on the local endothelial and epithelial tissues to enhance the migration of the leukocytes toward infected epithelial cells, which in turn, participate in the cytotoxic injury of infected cells as well as nearby bystander cells (40).

Some studies have shown Azithromycin to be highly effective in reducing muscle enzyme Creatine Kinase, Lactate Dehydrogenase, Interleukins (IL-4, IL-6, IL 10 ), levels of C reactive protein(CRP) and increase levels of CD3+, CD4+ and 
Serum ferritin is a well-known acute-phase reactant, denoting acute and chronic inflammation in infectious, rheumatologic, hematologic and malignant disease. In general, serum ferritin is glycosylated and has a high ratio of Ferritin light chain (FTL) to Ferritin heavy chain (FTH) whereas intracellular ferritin is not glycosylated (43). The FTL has a site for $\mathrm{N}$-glycosylation, which is die to post-translational modification of the protein as it moves through the Golgi apparatus to its site of secretion (44). Additionally, the relative contributions of glycosylated and non-glycosylated ferritin to serum levels are also altered during a disease. Normally, the glycosylated fraction (GF) of serum ferritin is $\sim 50 \%$. But the recorded elevations in serum ferritin are accompanied by low levels of glycosylation, typically $\leq 20 \%$ (4548 ) in certain severe infections, hemophagocytic syndromes and drug-induced hypersensitivity reactions, regardless of etiology $(49-51),(52,53)(50)$. However, the degree of glycosylation may help distinguish underlying pathology (42).

\section{Drugs that have been effective in treatment and severity of COVID 19 are:}

\section{DRUGS}

Azithromycin (AZT) is a macrolide and a phospho-glycoprotein inhibitor which has a very important role of transportation of viruses, bacteria and drugs into the cells of the body, which the viruses need for replication. Higher doses have been studied for their role as antiviral and the capabitlity of this macrolide to stop the replication and reduce proinflammatory markers. (40) The lung epithelium, which produces interferons (IFNs) upon infection with virus like retrovirus, is the mainstay in the antiviral defense of the lung and leads to the stimulation of interferon genes that directly interfere with virus replication $(13,14)$. Cellular studies have shown that IFN-1 is important for host defense against certain retroviruses, and treatment with endogenous IFN showing reduction in viral load in-vitro cell culture cells (15-17). This highlights the importance of IFNs as therapies to control replication of retroviruses in the lung alveolar cells and highlights the potential of IFN inducers such as Azithromycin as treatment for virus-associated exacerbations, even in patients of cystic fibrosis.

Azithromycin pre-treatment reduced viral replication in cystic fibrosis bronchial cells, due to the antiviral response via the IFN pathway.

In conclusion, the antiviral effect is achieved only after increasing the dose demonstrated by the exposure of lung and bronchial washing to azithromycin by doubling the dose to $1000 \mathrm{mg}$, which results in more effectiveness of the drug in the lower respiratory tract (43).

Pentoxifylline (PTX) is a methylxanthine derivative having a highly significant role in management of deep venous thrombosis and intermittent claudication.. (11). It has been shown to have anti-inflammatory, antiviral, immunomodulatory and bronchodilator properties in many molecular studies (12-14). PTX has also been found to be have broad spectrum anti-viral activity, through prevention of viral replication and has been used as an anti viral agent against viruses like herpes simples, rotavirus, vaccinia virus, human immunodeficiency viruses (HIV), SARS, etc. (15-18).

D dimer is the by product of fibrinolysis and PTX increases cAMP levels in polymorphonuclear leukocytes, decreasing micro vascular thrombosis and haemorrhage and also has an important function of an anti-inflammatory agent by inhibiting the production of pro-inflammatory cytokines. (19-22). It also acts as bronchodilator by reducing blood viscosity and increasing red blood cell flexibility thereby making it easier for them to migrate through narrow capillaries rapidly, increasing blood circulation (23-26). This creates perfusion and enhances oxygenation to all the tissues and organs including lungs as it halso has a role of a bronchodilator. Being widely available and cost effectivity, it can be a promising drug target for SARS COVID-19 treatment, either alone or in combination $(25,27-29)$. 
Pro-inflammatory cytokines released by stimulated macrophages in the alveoli could have a prominent role in pathogenesis of SARS. Previous studies on treatment of SARS with antiviral agents such as ribavirin and corticosteroids have not achieved very satisfactory results. Corticosteroids exert an anti-inflammatory effect and are indicated for the treatment of respiratory distress, but on the other hand, they exert an immunosuppressor effect on humoral and cellular immunity. PTX could have an antiviral role along with immunomodulating effect, down-regulating proinflammatory cytokines but not effecting the immune response.

Itraconazole (ICZ) is an anti-fungal agent has also been recently explored as a potential treatment option for COVID19. It's an anti-fungal, increases the expression of $P$ glycoprotein (transporter protein), THE MAINSTAY IN THE VIRAL GLYCOPROTEIN PATHWAY.

This drug inhibits Lanosterol 14a-demethylase (CYP51A1) which is a cytochrome P450 enzyme

It has been found to be effective against a wide range of viruses like rhinoviruses etc. (30-32). Recent studies show its role against type 1 feline coronavirus infection .(33). ICZ acts by interfering with the ergosterol synthesis pathway of the host cell thereby inhibiting cytochrome P450 enzyme, the lanosterol 14a-demethylase, which impairs cholesterol homeostasis (34-36). This disruption in the sterol synthesis shifts IFN-1 expression levels, accelerating the virus-induced host cell response. IFNs often serve as the first line of defence against viral infections. ICZ inhibits proliferation of endothelial cells by inhibition of 14-demethylase and sterol biosynthesis (37). The sterols like cholesterol are the chief components of the lipid pathways and play a central role in the viral entry into the host cells. Through these lipids, viral genome fuses and releases into the host cell. Viruses attack the host lipid pathway and and upregulate them to enchance their own replication thus form a viral cell membrane $(38,39)$. Hence, targeting the lipid metabolism pathways in the way that ICZ does could constitute an early-intervention option for SARS-COV2 cases.

It's a highly effective anti-angiogenesis factor where in it acts by inhibiting VEGF A and C through their receptor VEGFR and plays an important role in inhibiting other inflammatory cytokines (Figure 1). This could also be used with PTX as a preventive therapy for SARS COV2.

Ceftriaxone is a highly potent phospho-glycoprotein which also induces interleukin-10 action. The anti-inflammatory effect of IL-10 is critical to protect the host from tissue damage during acute phases of immune responses. Hence the viruses can evade immunity by hijacking this regulatory mechanism and cause tissue damage in the acute phase. This regulatory interleukin can be produced by almost all cells involved in the immune mechanism., and it has a very important action of immune modulation. The cytokine has very complex and multifunctional in inflammatory response to acute viral infections. There are various factors involved in IL-10 production and the cellular sources of the cytokine during antiviral immune responses. IL-10 regulatory mechanisms have an impact on antiviral immune responses and how viruses can use this central regulatory pathway to evade immunity and establish chronic infections, hence these regulatory mechanisms play an important role in fulminant viral infection, and are highly important factors to be considered in COVID 19 infection. Antiviral immune responses ideally eliminate replicating virus and viral reservoirs without host damage. However, in many infections, severe complications could occur due to excessive immune activation. To prevent host tissue damage, immunoregulatory cytokines control the magnitude of these immune responses. IL-10 is a key component of this inflammatory mechanism that regulates and suppresses the expression of proinflammatory cytokines during the recovery phases of infections and consequently reduces the damage caused by inflammatory cytokines

Dexamethasone is a long acting immune modulatory steroid which has been shown to be have lifesaving properties in COVID-19 patients. Dexamethasone therapy leads to a rapid, clinically beneficial effect that may be due to upregulation of IL10 production and strong immunosuppressive effect, which is most evidently observed in the decrease in Interferon gamma., and enhances T2 cell activity. In vitro evaluation showed that this shift in T cell balance was a direct effect of 
dexamethasone and thus independent of the hypothalamic-pituitary-adrenal axis. It has an inducing effect on the CYP3A4 activity and hence should not be given concomitantly with Itraconazole.

\section{Comparative profile of severe patients in SECTION 1 and SECTION 2}

In the first section we report a comparative profile of a total of five severe cases with varied co-morbidities managed through combination of above repurposed drugs over a period of 14 days. These drugs have been combined with other Phospho-glycoprotein inhibitors like Pantoprazole, Metformin for Diabetes, Telmisartan for hypertension, Amiodarone for arrythmias specific for the comorbidities. And Nitazoxanide for gastrointestinal system involvement.

In the second section we have discussed case histories of severe patients with and without comorbidities affected with the double mutant virus strain that has been causing a very high mortality We studied the effectivity of these combination drugs in the double mutant viral strain during the second wave affecting Indian community and causing severe symptoms in these patients

\section{Section 1 - First Wave Of Covid 19 In 2020 DISCUSSION:}

COVID-19 has been a deadly pandemic that has affected millions of people worldwide with a high mortality rate. According to previous research studies, the positive sense single strand virus has been implicated for many pathways including coagulation cascade, cardiac myopathies, lung fibrosis and inflammation. Neurological involvement with stroke and myocardial infarction as an outcome in some of the patients has become deadly killer in our population.

In the cytokine storm, the likely initiating sequence of pathological thrombosis in patients with COVID-19 is a hyperinflammatory response with resultant 'cytokine storm' (13). Patients with COVID-19 have elevated levels of both interleukin-6 (IL-6) and C-reactive protein (10). Moreover, IL-6 perpetuates the hypercoagulable state associated with COVID-19 through (1) induction of TF expression in mononuclear cells; (2) triggering acute endothelial cell activation, also resulting in expression of TF; (3) activation of acute phase response resulting in enhanced production of fibrinogen by hepatocytes; and (4) platelet hyper activation and aggregation $(10,14)$.

In the case series (Table 1), we tried to optimize the dosage and drug protocol in various age groups and patients with different co-morbidities.

The case number one was a 49-year-old male having high cholesterol, hypertensive and obese. As soon as he developed fever, he was given cephalosporins which didn't prove to be effective. His blood reports showed elevated serum ferritin, high LDH, D dimer, high CRP and IL6. His total creatine phospho-kinase levels were also moderately high but not as high to cause rhabdomyolysis.

We gave him Azithromycin $500 \mathrm{mg}$ twice a day for 5 days and his high-grade fever came to normal but started rising on the 5th day of taking the drug. We also gave Telmisartan for his high blood pressure and tab Itraconazole $200 \mathrm{mg}$ once a day for 5 days.

His oxygen saturation started dropping after the $5^{\text {th }}$ day, hence supplemental oxygen was given at home, which corrected his oxygen levels. The third surge came after $11^{\text {th }}$ day when he developed high grade fever and acute shortness of breath and he was started on Pentoxifylline $400 \mathrm{mg}$ thrice a day. The next day also his fever stayed high, and his oxygen fell to 85 percent with acute shortness of breath. And respiratory rate reaching 25 , so as a trial of a 
combination therapy, he was given a combination of Azithromycin $1000 \mathrm{mg}$ with Pentoxifylline $400 \mathrm{mg}$ and Dexamethasone $6 \mathrm{mg}$ orally.

In 6 hours, his fever came down to normal and his oxygen level reached $93 \%$ and shortness of breath improved considerably. He was kept in the hospital for observation as he was improving the first day, but the patient stopped these combination drugs after one dose, and his oxygen saturation started dropping the $2^{\text {nd }}$ day and on the $3^{\text {rd }}$ day he again developed shortness of breath and his respiratory rate reached $30 / \mathrm{min}$, so he was shifted to the ICU where he was put on high flow oxygen

(HFO) and the chest Xray showed that Viral Pneumonia and mild fibrosis of lung had developed. He was started on intravenous ceftriaxone $1 \mathrm{~g}$ twice a day with dexamethasone $8 \mathrm{mg}$ but as he deteriorated even after low molecular heparin, he was also given two injection Tocilizumab $600 \mathrm{mg}$ in a week. His condition slowly and gradually got better but the lung fibrosis was almost 70 percent when he was discharged. After the discharge due his fibrosis, he was having difficulty walking. And climbing stairs. So, we started on Tab Pentoxifylline $400 \mathrm{mg}$ SR thrice a day with Cap Itraconazole $200 \mathrm{mg}$ once a day for 8 weeks. His lungs improved considerably, and oxygen saturation also improved to $96 \%$.

In the second case, we modified the drug protocol. The patient had already taken ayurvedic syrups before the start of treatment. So, the patient was asked to stop that and start the combination treatment. The fever got normal the next day and metformin $500 \mathrm{mg}$ was given for Diabetes and Telmisartan $40 \mathrm{mg}$ was given for hypertension for the first 5 days. But subsequently after the treatment with pentoxifylline, her blood pressure started getting normal. Patient got better after a week but developed metabolic acidosis and a tachycardia and hence was admitted to the hospital. After correcting the metabolites and observation in the ward, she was discharged. The patient in this case had taken a lot of local made medicines and we think that may have caused the subsequent problems. Her follow up consisted of Metformin and glipizide along with pantoprazole $40 \mathrm{mg}$ daily. After 3 months she was having no symptoms and her sugar was under control.

In the third case, the 49-year-old obese and diabetic female, having a significant past medical history, was started on the combination therapy of the three drugs after titration of her diabetic medication. Due to interaction of metformin with the drugs, we stopped the metformin but gave insulin for her diabetes. She tolerated the medicine very well and her oxygen fluctuation levels got better. But when she was started on Itraconazole $100 \mathrm{mg}$ she could not tolerate it. Hence it was discontinued. She continued with pentoxifylline $400 \mathrm{mg}$ twice a day and metformin was resumed.

Total drug protocol was given for 14 days, and she tested negative for COVID on the $18^{\text {th }}$ day.

On CT and having mild ground glass appearance, so she was advised to get intravenous Ceftriaxone $2 \mathrm{~g}$ twice a day for the first day followed by $1 \mathrm{gm}$ BD for the next 4 days. There was no fatigue after that, and she recovered fully in 20 days. Her IgG antibodies were 15 after 30 days.

The Case number four was of an elderly male of 83 years, a previous case of Acute Coronary Syndrome and hypertension. He was taking medical treatment for the same. He was also taking medication for high uric acid. We stopped some of the medicines but continued Aspirin $75 \mathrm{mg}$, Apixaban $2.5 \mathrm{mg}$ twice a day and Nitrates along with COMBINATION THERAPY of Azithromycin 1000mg, Pentoxifylline $400 \mathrm{mg}$ twice a day and Dexamethasone $4 \mathrm{mg}$.

This was given for 5 days along with Nitazoxanide $600 \mathrm{mg}$ twice a day. After that the patient was asked to continue Pentoxifylline 400mg twice along with Dexamethasone $4 \mathrm{mg}$ on the first day and then reducing the dose by $1 \mathrm{mg}$ every day for 3 days. On the 4 th day, Dexamethasone was stopped and Itraconazole $200 \mathrm{mg}$ once a day with and Pentoxifylline $400 \mathrm{mg}$ SR thrice a day were started. Apixaban and Aspirin were stopped for a period of 5 days. His Chest 
CT was done which showed very few lesions in the basal area. He recovered fully but developed leg infection after 15 days for which he was given intravenous ceftriaxone $2 \mathrm{~g}$ once a day. He recovered fully within a month.

His He resumed rest of his medications but continued dexamethasone $0.5 \mathrm{mg}$ with Pentoxifylline $400 \mathrm{mg}$ twice a day for 2 months. His electrolytes had to be monitored due to age. Overall, it was a remarkable recovery. He had an episode of Angina which got relieved with Sorbitrate. This Patient also had been doing deep breathing. His oxygen saturation maintained at $96-97 \%$.

The case number five was a 44-year-old male having high cholesterol with morbid obesity. He had remarkably high cholesterol, Triglycerides, low RBC count, low absolute lymphocytes, and eosinophil count.

He developed high fever along with shortness of breath, nausea, and headache. This three-drug regime was given for a period of 5 days followed by pentoxifylline thrice a day with dexamethasone reduction by 0.5 mg every day. After stopping Dexamethasone, he was given Itraconazole $200 \mathrm{mg}$ once a day along with Pentoxifylline $400 \mathrm{mg}$ SR thrice a day. On day 5 of treatment, he developed loss of smell and taste. The full treatment was given for 14 days. He had no complaints and there was no fever or cough, Complete loss of taste and smell persisted till the $14^{\text {th }}$ day. On the $15^{\text {th }}$ day it returned by $50 \%$ and within 2 days he recovered completely

After the treatment he was advised to get HRCT and blood tests.

His total CT score was 4/25 with mild ground glass opacity which resolved on its own, but he was not given any treatment as he had no symptoms. His follow up after 15 days was flawless.

\section{Section 2 - Second Wave Of Covid 19 In 2021}

DISCUSSION: The second wave of Pandemic hit India with a bang. The double mutant virus proved to be highly virulent and high mortality was observed especially among women. The pathway of this double mutant virus strain afflicting women more than should be studied. Furthermore, high mortality was seen in patients taking standard treatment where recovery even in mild to moderate cases was prolonged and severe cases developed acute respiratory distress syndrome (ARDS).This double mutant has been deadly affecting gastrointestinal system along with the coagulation pathways.

We would like to highlight the fact that these medicines had a lowering effect in the virulence of the virus, decreasing the symptoms and need for oxygen supplementation. Along with the medication, lifestyle changes were advocated to the patients. Low fat diet and exercises were included to bring about complete recovery. The severe patients needed regular monitoring for around 14 to 17 days followed by complete recovery. Mortality was lowered with the same combination therapy that was used for the single mutant virus strain in the first wave of Pandemic in 2020.

\section{CASES OF PATIENTS WITH SEVERE COVID IN THE SECOND WAVE IN INDIA}

Patient 1: After getting COVID positive, developed fever for which he was started on Azithromycin 1000mg, Dexamethasone $4 \mathrm{mg}$ and Pentoxifylline $400 \mathrm{mg}$ SR. The second day, her fever subsided but she developed cough, and Azithromycin was stopped. Subsequently, after 4 days she started having high grade again (102.4) for which was given intravenous Monocef, High fever of around 101-103 persisted for 4-5 days and then subsided to around 100. She also complained of loose stools during the treatment with IV Monocef for which she was given Nitazoxanide 600 mg with Dexamethasone $4 \mathrm{mg}$ and Pentoxifylline $400 \mathrm{mg}$ SR twice a day. She developed breathlessness around the 9th day and oxygen level dropped to 87 twice, which was treated by administering oxygen at home. She simultaneously did deep breathe exercises. and her oxygen levels came to 94 . She was asked to get a HRCT scan which showed a CT severity score of 9 out of 25. After IV Monocef dosage was complete, she resumed Azithromycin 750 mg for 3 days. Fever was 
persistent but low grade by day 10. After Azithromycin dosage was complete, she took a combination of Pentoxifylline and Itraconazole to treat inflammation. Fever finally subsided after 2 days of combination treatment. Her CRP and LDH stayed high all through the treatment with high and low spikes associated with transient fall in oxygen saturation which got recovered within a few minutes. The IL6, LDH, CRP levels kept fluctuating even after the treatment but slowly started resolving. The patient had full recovery.

Patient 2: A 48-year female patient came with chief complaints of fever (99-100) for the first three days after taking the second dose of Covaxin. When fever increased to 101, accompanied with body aches, patient was asked to take Aceaminophen 650 . When the fever did not subside and was accompanied by increase in dry cough and sore throat even after seven days, she was advised to get blood tests done. Her CRP and D-Dimer levels were high (Table 4). She lost her sense of smell and taste. She was prescribed Pentoxifylline 400 mg SR, Dexa 6mg and Azithromycin 1000.mg Patient developed COVID induced acute sinus tachycardia. As the patient complained of intolerance to Azithromycin, it was stopped. After the HRCT report showed a CT severity score of 9, patient was started on IV infusion of Ceftriaxone 2 $\mathrm{g}$ BD.for 3 days reducing to $2 \mathrm{~g}$ once a day for 3 days.. Along with it, she was given Pentoxifylline 400 mg one a day with Dexamethasone $4 \mathrm{mg}$. in two divided doses. During the therapy lymphopenia developed so Ceftriaxone was given once a day for two days and stopped. She regained her sense of smell and taste after 7 days from beginning of therapy. RT PCR test was negative on the $14^{\text {th }}$ day. Repeat CT was not done but repeat blood tests high LDH and CRP. The patient had cough for which pentoxifylline was increase to three times a day with dexamethasone $2 \mathrm{~g}$. She was also put on a bronchodilator Ambroxol hydrochloride. Cough was incessant so Dextromethorphan was given SOS. Two days later, dry cough subsided and was accompanied with expectoration. She developed fever on the $11^{\text {th }}$ day again. Her CRP levels were high again. She was asked to take lots of fluids and vitamins and deep breathing exercises. Finally for her fever, she was prescribed Cefixime 200 BD for 5 days, presuming it to be secondary bacterial infection.. Her fever subsided and full recovery was seen after 17 days.

Patient 3: An 84-year-old male, hypertensive with coronary artery disease came with chief complaints of fever and body aches. The fever was high grade accompanied with body aches. His RT PCR tested positive for COVID 19. He was given Aceaminophen 650 for fever and advised to get routine blood tests with inflammatory markers and Electrocardiography. Tests showed Lymphopenia, neutrophilia, high RBC count, low platelet count. The inflammatory markers CRP and LDH were also. Interleukin 6 and serum ferritin was higher than normal. He was started on treatmet but was advised to monitor his blood pressure and pulse apart from oxygen saturation. The D Dimer value was higher than reference range (table) so he was also started on Apixaban $5 \mathrm{mg}$ Azithromycin caused significant fluctuation in pulse rate especially sinus bradycardia during sleep. Patient was shifted to IV Ceftriaxone $2 \mathrm{~g}$ BD for 2 days, followed by $2 \mathrm{~g}$ once a day for 3 days.. Fever subsided by $3^{\text {rd }}$ day of medication and the CT severity score after the therapy was 3 out of 25, ECG was normal study. Patient continued Apixaban and Pentoxifylline twice a day and gradually reducing dosage of Dexamethasone to $0.5 \mathrm{mg}$ before completely stopping the medicines on the $21^{\text {st }}$ day from the symptoms. Patient had a remarkable recovery, and he kept his walk and exercises regularly.

A SPECIAL CASE OF SECOND PANDEMIC IN 2021.

THIS PATIENT REQUIRED FOLLOW UP FOR ONE MONTH. SHE HAS 100 PERCENT RECOVERY .

Patient 4: A 72 year old morbidly obese female, having previous history of Bronchial Asthma, (spo2 stayed around 91 to 92\%) since many years, Hypothyroidism, Uncontrolled Type 2 Diabetes mellitus, Hypertension came with chief complaints of acute shortness of breath, high grade fever, nausea, vomiting. She got tested for SARS Cov 2 RT PCR and it came out to be positive. Her fever was not subsiding with antipyretics and her oxygen saturation was falling to $85 \%$. She was unable to walk to the washroom due to acute shortness and her oxygen levels while walking for 3 minutes would fall to $77 \%$. After sitting the recovery would lead to oxygen levels at 83 to $85 \%$. Her pulse rate was 115 to 120 per

Page $10 / 28$ 
minute and she was very lethargic and complaining of loss of appetite and fatigue .Her Pulse rate was fluctuating and her Blood pressure was higher.

Her HRCT could not be performed and she refused to be hospitalised.Her sugar levels were high despite the antidiabetic medication. She was asked to get her blood tests before the therapy and her blood test reports were as follows;

CBC- HB-low(11.8mg/dl)

TLC-normal

DLC-Lymphopenia(absolute count 894cu.mm)Eosinopenia (0.02)

Ddimer- normal, $0.56,1.89,0.49,0.41$, after follow up at 30 days - 0.3 -Normal

Serum ferritin $-596,779,413$ ( high during treatment , after treatment- 198, after follow up of 30 days, 176- Normal

CRP : $14.65,64.89,56.45,6.4$ After follow up of 30 days, CRP-13.24 (Ref. range $<0.5$ )

LDH: 398 , 576, 489, 198( Ref range 100-250 ) ,after 30 days follow up - Normal

ESR -30MM/HR (high)(0-20mm/hr) follow up after 30 days: Normal

TSH-8.77 high (0-5mg/dl) after 30 days follow up - Normal

FASTING SUGAR-190, fluctuating. Didn't require long acting insulin. Given only metformin 500 mg BD.

LFT- SGPT- $64 \mathrm{mg} / \mathrm{dl}(25-49), 69,55,30$. After follow up of 30 days: normal

Total Bilirubin-0.25(0.30-0.60) normal after 30 days

Renal function tests were normal through out.

IL6 WAS DONE ONLY ONCE DUE TO THE COST, IT WAS BORDERLINE HIGH.

Mannagement: She was started on pantopraole 40 mg BD with Acetaminophen 650 for her fever. Pentoxifylline $400 \mathrm{mg}$ SR was given along with 2 divided doses of Dexamethasone $6 \mathrm{mg}$ after food. Azithromycin $1000 \mathrm{mg}$ was given once a day before food. And Apixaban $2.5 \mathrm{mg}$ was given BD.

Her fever resolved the next day after taking the combination therapy. Her spo2 improved to $90 \%$ but walking caused tachycardia and a fall in oxygen to $85 \%$. She was recommened oxygen concentrator at home. And asked to do deep breathing exercises along with 2 litre water and juices. . She was asked to stop taking any animal protein and instead diet was modified to plant flavonoids and green veggies. On 5 th day her fatigue was much better but walking did create shortness of breath. Her blood tests on the 4 th day showed high serum ferritin and CRP level.

Her TLC was also raised to 14000 cu.mm but there was no fever . there was mild monocytosis, but lymphopenia improved. We recommended HRCT scan but she declined due to cost. Hence we started with intravenous Infusin of Injection Ceftriaxone $\mathbf{2} \mathrm{g}$ twice a day as her serum ferritin was higher. The dose was given for 3 days $\mathrm{BD}$ and then $2 \mathrm{~g}$ OD for another 4 days. She was given this along with pentoxifylline $400 \mathrm{mg}$ SR 3 times a day and dexamethasone was tapered and stopped and subsequently after a day itraconazole $200 \mathrm{mg}$ OD was started. But after 2 days she developed a rash (which she complained of having before treatment due to Diabetes but we stopped the medicine. She recovered completely, sugar levels were maintained with metformin $1000 \mathrm{mg}$ and gliclazide $\mathbf{4 0} \mathrm{g}$. 
After 15 days of follow up her TLC count was high at 13000 along with high Lipids and very low platelet count. She was taking Aspirin75 mg , so we stopped it and put her on short course of Dexamethasone in divided while managing her sugar levels. Her TLC count INCREASED to 24000 , so we put her on AZITHROMYCIN 1000 MG along with pentoxifylline and continued low dose dexamethasone afor another week. Her counts resolved and she her sugar levels were steady. All the blood tests were nirmal except mild lymphocytosis. After stopping all medication, we put her on itraconazole 200 $\mathrm{mg}$ BD alone after modifying other drugs for her high lipds.

We have still kept her case for follow up due to long Covid in the double mutant strain.

\section{Discussion}

The second wave was caused due to the double mutant strain of the virus and the transmissibility was very high as predicted in some studies. The cases showed increased severity and the pneumonia symptoms started as soon as the cases were positive for the virus. Along with the nausea, vomiting and fever, some cases included diarrhoea, abdominal cramps and malaise as accompanying symptoms. In the first wave of the pandemic, we had initiated oral therapy in cases having severe symtoms loke fever, shortness of breath and low oxygen saturstion. But in the second wave, intravenous infusion of Ceftriaxone high dose had to be initiated early. After the infusion for 5 days, cases recovered but spikes high total leucocyte count, high lipds, high liver function tests were observed. These were treated according to the symtoms. For symptoms of high lipids, Itraconazole was given for a period of 12 days. For high TLC, Azithromycin with Pentoxifylline and low dose dexamethasone was given.

In severe patients, having alveolar changes, Pentoxifylline and Itraconazole were given for a period of 4 weeks. All the hemodynamic changes brought about due to the viral infection and subsequent inflammation got reversed in a matter of 14 days. Pentoxifylline was highly effective in patients having sore throat, with cough. It also was very beneficial in altered liver function tests and Diabetes. As it does not has interaction, it could be safely administered in all the patients with comorbities like cancer and coronary artery disease. After initiating treatment with these drugs, walking, yoga and pranayama proved to be very beneficial in stabilizing the oxygen satuation in severe patients.

We were successful in complete management of the cases and complete recovery.

\section{Conclusions}

The combination of pantoprazole with high dose Azithromycin, Pentoxifylline and low to moderate dose of Dexamethasone brought about complete recovery in severe and critically ill patients of COVID 19. This combination has been shown to be helpful in blocking TLR mediated immunity in some cellular studies, which has been responsible for the hyperinflammatory syndrome and cytokine storm.

This is a home based therapy and has the most beneficial results when initated early within seven to ten days of the onset of symptoms. The combined drugs have proven to be highly effective in reversing Pneumonia, fibrosis and other abnormalities either in the lungs, or the coagulation system. The Diabetics were also managed with Metformin and long acting insulin and their recovery was also remarkable.

\section{Learning Points}

1. The combination of pantoprazole $40 \mathrm{mg} \mathrm{BD}$ with Azithromycin $1000 \mathrm{mg}$, Pentoxifylline $400 \mathrm{mg}$ SR and Dexamethasone $4 \mathrm{mg}$ brought about complete recovery in most moderate to severe patients. This combination has been shown to be helpful in blocking TLR mediated immunity in some cellular studies. 
2. Azithromycin, Pentoxifylline and Dexamethasone lowers proinflammatory markers like IL-1 beta, IL-6, TNF-alpha, CRP.

3. Dexamethasone is an inducer of CYP3A4 and hence should not be used with warfarin in valvular heart disease.

4. In critical patients who have high serum ferritin, LDH and D dimer or IL6, Itraconazole 200 mg with Pentoxifylline $1200 \mathrm{mg}$ to $1800 \mathrm{mg}$ in 3 to 4 divided doses can inhibit or reverse cytokine storm or fibrosis in the lung in patients with Bronchial Asthma, COPD or Interstitial lung diseases.

5. The combination of Pentoxifylline and Itraconazole could be given safely to patients with heart diseases.

6. Azithromycin was not administered to patients with Atrial fibrillation, Prolonged QT interval, brugada syndrome. These patients were given IV Ceftriaxone $2 \mathrm{~g}$ BD as infusion in normal saline for first two days followed by $1 \mathrm{~g} \mathrm{BD}$ for the next 3 to 5 days depending upon the severity. It led to complete recovery within a period of 14 days. There was no reinfection even after 3 months follow up.

7. In patients having a high D DIMER, Apixaban $2.5 \mathrm{mg}$ along with pentoxifylline 800 to $1200 \mathrm{mg}$ in 3 divided doses and dexamethasone $6 \mathrm{mg}$ to $8 \mathrm{mg}$ was given for a period of 5 days. On the $6^{\text {th }}$ day, only Pentoxifylline $1200 \mathrm{mg}$ with Itraconazole $200 \mathrm{mg}$ was given for a period of 5 days.

8. Azithromycin showed a lowering effect of LDH and CRP in severe COVID patients.

9. High doses(1000-2000mg) of Azithromycin have shown an antiviral effect in some cell studies and we found 1000 mg once a day of Azithromycin to be safe in all our patients.

10. Itraconazole showed to be safer and more efficacious than Tocalizumab due to its effect on CYP 3A4 enzyme pathway. Apart from VEGF A and C inhibitor, it also has shown anti-inflammatory properties and anti-fibrinolytic activity along with Pentoxifylline. It also exerts an anti-inflammatory effect on interleukin 6 and given essentially to patients having high serum ferritin due to its acute phase reactant activity.

11. This combination therapy of repurposed has shown promising results in severe to critical COVID 19 patients having all kinds of comorbidities. This home-based therapy has also shown efficacy in new mutant strains as well.

12. We suggest this home-based therapy to all the patients with or without comorbidities with dose adjustments. and measurements of blood parameters. Wherever required oxygen therapy can be provided at home.

13. In hypertensives, Telmisartan has shown to be drug of choice in COVID positive patients. While Metformin has been used for Diabetic and pre diabetic patients.

Key points to remember.

1. Azithromycin $1000 \mathrm{mg}$ should be given to all patients who have a history of heart disease after an assessment of QT interval, any congenital syndromes of heart and all arrhythmias.

2. Ceftriaxone should not be administered to patients having hepatitis $B, C$ or increased serum bilirubin.

3. Pentoxifylline is a very safe and effective drug in Acute coronary syndrome and coronary artery disease patients or any valvular disease.

4. It also can be safely administered to patients with Diabetes and Autoimmune disorders.

5. Itraconazole should not be administered with metformin and it increases the dosage of itraconazole when given concomitantly.

6. Dexamethasone should not be given along with Itraconazole as it may reduce the effectivity of itraconazole.

7. Pregnant women in the third trimester were given these drugs safely and full recovery was seen.

8. Treatment of a 6-month-old infant was successfully done using high dose Azithromycin and Dexamethasone.

9. High dose Itraconazole has a major role in reducing Hyperlipemia in COViD 19.

Page $13 / 28$ 
10. The combination of Itraconazole $100 \mathrm{mg}$ with Pentoxifylline $400 \mathrm{mg}$ SR could be a potential preventive therapy for COVID19.Further studies are required to analyse the effect of this combination as lipid rafts play a major role in host entry of the virus. Itraconazole has the potential to inhibit it.

\section{Action Of Azt (Azithromycin)}

IT IS A POTENT ANTI VIRAL AND ANTII INFLAMMATORY P GLYCOPROTEIN INHIBITOR ESSENTIAL IN INHIBITING THE .VIRAL REPLICATION

- has a reducing effect on viral load and viral progeny (replication) in diseased epithelium.

- has an effect on LDH levels.

- reduces expression of Type I-III interferons in lung

- overexpresses helicases and interferons in viral infection

- decreases the levels of TNF-a. (Rhinovirus increase TNF-a.)

- Did not alter the interferon expression in healthy epithelial cells of lungs

\section{EFFECT OF DEXAMETHASONE}

- Reduction of TNF-a

- Reduction of IL-6

- Reduction of CRP

- Reduction of IL 1 beta

\section{EFFECT OF ITRACONAZOLE ON ANGIOGENESIS}

- Potent VEGFA + VEGFC inhibitor through CYP 3A4 pathway inhibition.

- Reduces angiogenesis (STAT 3 signalling)

- Reduces expression of VEGF and its receptors, pro inflammatory cytokines induced in Angiogenesis.

- Other effects include its effect on lipid pathway.

- A high dose has shown to reduce Cholesterol, LDL-C

\section{EFFECT OF PENTOXIFYLLINE ON INFLAMMATION}

- Reduces pro inflammatory and Increases anti-inflammatory activity

- Pro inflammatory:

- Reduces IL-6 \& IL- 12

- Reduces CRP \& TNF-a

- Increases Anti-inflammatory:

- Increases TGF-ßeta

- Increases IL-10

- Has broncholdilatory effect in lungs

- Stops formation of microthrombi formation in small vessels.

- Has a blood thinning effect along with itraconazole. 


\section{SYNERGISTIC EFFECT OF AZT + DEXA + PTX \\ (AZITHROMYCIN+DEXAMETHASONE+PENTOXIFYLLINE)}

- Inhibition of toll like receptor mediated (TLR) immunity, responsible for cytokine storm.

- Reducing viral load and inflammation

- Reducing the cytokine storm

- Induciing anti inflammatory marker like Interleukin 10

\section{SYNERGISTIC EFFECT OF ITRA + PTX}

- Enhance anti fibrotic and anti-inflammatory effect in lungs

- Reduction in the LDL-Cholesterol pathway induced by COVID 19

- Act as blood thinners essential in clot formation in COVID 19.

\section{Declarations}

1. As these were case reports performed with our research-based therapy through telemedicine and OPD, ethical approval was not required.

2. The data or any information regarding the case studies shall be made be available for review.

3. The authors have no conflict of interest in the publication of this case series.

4. Signed Informed consent was taken from all patients.

5. There were no funding authorities involved in these case series.

6. The First and corresponding author has researched, designed the drug protocol, and treated severe COVID 19 patients in both the first and second epidemic in India. The first author had contributed to the design of case series.

7. The other authors were involved in the preparation of the data and material required for the case studies.

8. The supplemental data will be shared of these patients when required.

\section{ACKNOWLEDGEMENTS:}

A very special thanks to Dr Vijai Kumar, President, Dayalbagh Satsang sabha, Head Consultant and Medical Advisor, Dayalbagh Educational society, Dayalbagh, Agra,UP,India. Ex Director, Department of Internal medicine, PD Hinduja Hospital, Mumbai, India, for his contribution toward following and monitoring his patients with this drug protocol for severe COVID patients.

We are also grateful to our volunteers, Ms Piya Bajwa, Founder, For Ability India Trust, Mr Ashish Bindra, Regional Manager, Amity University, Noida, UP, India, Ms Sonia Nayyar, Ms Manpreet Gill ( Ex Major, Indian Army) for monitoring required for home-based therapy of all the patients.

\section{References}


1. Verity R, Okell LC, Dorigatti I, Winskill P, Whittaker C, Imai N, et al. Estimates of the severity of coronavirus disease 2019: a model-based analysis. The Lancet infectious diseases. 2020.

2. Fehr AR, Perlman S. Coronaviruses: an overview of their replication and pathogenesis. Methods Mol Biol. 2015;1282:1-23.

3. Stohlman S, Baric R, Nelson G, Soe L, Welter L, Deans R. Specific interaction between coronavirus leader RNA and nucleocapsid protein. Journal of virology. 1988;62(11):4288-95.

4. Molenkamp R, Spaan WJ. Identification of a specific interaction between the coronavirus mouse hepatitis virus A59 nucleocapsid protein and packaging signal. Virology. 1997;239(1):78-86.

5. Lu Y-C, Chiang B-J, Pong Y-H, Huang K-H, Hsueh P-R, Huang C-Y, et al. Predictors of failure of conservative treatment among patients with emphysematous pyelonephritis. BMC infectious diseases. 2014;14(1):418.

6. Hurst KR, Koetzner CA, Masters PS. Characterization of a critical interaction between the coronavirus nucleocapsid protein and nonstructural protein 3 of the viral replicase-transcriptase complex. Journal of virology. 2013;87(16):9159-72.

7. Sturman LS, Holmes K, Behnke J. Isolation of coronavirus envelope glycoproteins and interaction with the viral nucleocapsid. Journal of virology. 1980;33(1):449-62.

8. Vankadari N, Wilce JA. Emerging COVID-19 coronavirus: glycan shield and structure prediction of spike glycoprotein and its interaction with human CD26. Emerging microbes \& infections. 2020;9(1):601-4.

9. Zahoor I, Haq E. Multiple sclerosis in India: Iceberg or volcano. Journal of Neuroimmunology. 2017;307:27-30.

10. Padoan A, Sciacovelli L, Basso D, Negrini D, Zuin S, Cosma C, et al. IgA-Ab response to spike glycoprotein of SARSCoV-2 in patients with COVID-19: A longitudinal study. Clinica Chimica Acta. 2020;507:164-6.

11. Samlaska CP, Winfield EA. Pentoxifylline. Journal of the American Academy of Dermatology. 1994;30(4):603-21.

12. Fujimoto T, Nakamura T, Furuya T, Nakane S, Shirabe S, Kambara C, et al. Relationship between the clinical efficacy of pentoxifylline treatment and elevation of serum T helper type 2 cytokine levels in patients with human Tlymphotropic virus type l-associated myelopathy. Internal medicine. 1999;38(9):717-21.

13. Doherty G, Jensen JC, Alexander H, Buresh C, Norton J. Pentoxifylline suppression of tumor necrosis factor gene transcription. Surgery. 1991;110(2):192.

14. Frampton JE, Brogden RN. Pentoxifylline (oxpentifylline). Drugs \& Aging. 1995;7(6):480-503.

15. Zeman D, Adam P, Kalistova H, Sobek O, Kelbich P, Andl J, et al. Transferrin in patients with multiple sclerosis: a comparison among various subgroups of multiple sclerosis patients. Acta neurologica scandinavica.

2000;101(2):89-94.

16. Sebastian L, Desai A, Madhusudana SN, Ravi V. Pentoxifylline inhibits replication of Japanese encephalitis virus: a comparative study with ribavirin. International journal of antimicrobial agents. 2009;33(2):168-73.

17. Tovanabutra N, Chuamanochan M, Mahanupab P, Chiewchanvit S. REFRACTORY HYPERTROPHIC HERPES SIMPLEX GENITALIS: A POTENTIAL ROLE FOR PENTOXIFYLLINE AS ADJUNCTIVE TREATMENT AND SUPPRESSIVE THERAPY. Southeast Asian Journal of Tropical Medicine and Public Health. 2018;49(6):1002-8.

18. Dezube BJ, Lederman MM, Spritzler JG, Chapman B, Korvick JA, Flexner C, et al. High-dose pentoxifylline in patients with AIDS: inhibition of tumor necrosis factor production. Journal of Infectious Diseases. 1995;171(6):1628-32.

19. Fernandes JL, de Oliveira RTD, Mamoni RL, Coelho OR, Nicolau JC, Blotta MHS, et al. Pentoxifylline reduces proinflammatory and increases anti-inflammatory activity in patients with coronary artery disease-a randomized placebo-controlled study. Atherosclerosis. 2008;196(1):434-42.

20. Mandell GL. Cytokines, phagocytes, and pentoxifylline. Journal of cardiovascular pharmacology. 1995;25:S20-2.

21. Freitas J, Filipe P. Pentoxifylline. Biological trace element research. 1995;47(1-3):307-11.

Page 16/28 
22. Maldonado V, Loza-Mejía MA, Chávez-Alderete J. Repositioning of pentoxifylline as an immunomodulator and regulator of the renin-angiotensin system in the treatment of COVID-19. Med Hypotheses. 2020;144:109988.

23. Dhameliya H, Thakkar V, Trivedi G, Mesara S, Subramanian R. Pentoxifylline: An Immunomodulatory Drug for the Treatment of COVID-19. J Pure Appl Microbiol. 2020;14:861-7.

24. Haas F, Bevelaqua F, Levin N, Solazar-Schicchi J, Reggiani JL, Axen K, et al. Pentoxifylline improves pulmonary gas exchange. Chest. 1990;97(3):621-7.

25. Seirafianpour F, Mozafarpoor S, Fattahi N, Sadeghzadeh-Bazargan A, Hanifiha M, Goodarzi A. Treatment of COVID19 with pentoxifylline: Could it be a potential adjuvant therapy? Dermatologic Therapy. 2020.

26. DiNicolantonio JJ, Barroso-Aranda J. Harnessing adenosine A2A receptors as a strategy for suppressing the lung inflammation and thrombotic complications of COVID-19: Potential of pentoxifylline and dipyridamole. Med Hypotheses. 2020;143:110051.

27. Assimakopoulos SF, Seintis F, Marangos M. Pentoxifylline and complicated COVID-19: A pathophysiologically based treatment proposal. Med Hypotheses. 2020;143:109926-.

28. Zhang H, Alberts E, Pongratz V, Mühlau M, Zimmer C, Wiestler B, et al. Predicting conversion from clinically isolated syndrome to multiple sclerosis-An imaging-based machine learning approach. Neurolmage: Clinical. 2019;21:101593.

29. Thangaraju P, Gurunthalingam M, Varthya S, Venkatesan S, Thangaraju E. COVID-19: Older drugs for a novel disease-Chloroquine, hydroxychloroquine, and possible Pentoxifylline-set to start the second innings? Journal of Family Medicine and Primary Care. 2020;9(5):2172-5.

30. Shim A, Song J-H, Kwon B-E, Lee J-J, Ahn J-H, Kim Y-J, et al. Therapeutic and prophylactic activity of itraconazole against human rhinovirus infection in a murine model. Scientific reports. 2016;6:23110.

31. Schloer S, Goretzko J, Kühnl A, Brunotte L, Ludwig S, Rescher U. The clinically licensed antifungal drug itraconazole inhibits influenza virus in vitro and in vivo. Emerging microbes \& infections. 2019;8(1):80-93.

32. Zandee SEJ, O'Connor RA, Mair I, Leech MD, Williams A, Anderton SM. IL-10-producing, ST2-expressing Foxp3 + T cells in multiple sclerosis brain lesions. Immunology \& Cell Biology. 2017;95(5):484-90.

33. Takano T, Akiyama M, Doki T, Hohdatsu T. Antiviral activity of itraconazole against type I feline coronavirus infection. Veterinary research. 2019;50(1):5.

34. Vanden Bossche H, Bellens D, Cools W, Gorrens J, Marichal P, Verhoeven H, et al. Cytochrome p-450: Target for itraconazole. Drug Development Research. 1986;8(1-4):287-98.

35. van Luijn MM, van Meurs M, Stoop MP, Verbraak E, Wierenga-Wolf AF, Melief M-J, et al. Elevated Expression of the Cerebrospinal Fluid Disease Markers Chromogranin A and Clusterin in Astrocytes of Multiple Sclerosis White Matter Lesions. Journal of Neuropathology \& Experimental Neurology. 2015;75(1):86-98.

36. Schneider B, Gerdsen R, Plat J, Dullens S, Björkhem I, Diczfalusy U, et al. Effects of high-dose itraconazole treatment on lipoproteins in men. International journal of clinical pharmacology and therapeutics. 2007;45(7):377-84.

37. Aftab BT, Dobromilskaya I, Liu JO, Rudin CM. Itraconazole inhibits angiogenesis and tumor growth in non-small cell lung cancer. Cancer research. 2011;71(21):6764-72.

38. Abu-Farha M, Thanaraj TA, Qaddoumi MG, Hashem A, Abubaker J, Al-Mulla F. The Role of Lipid Metabolism in COVID-19 Virus Infection and as a Drug Target. International Journal of Molecular Sciences. 2020;21(10):3544.

39. Al Heialy S, Hachim MY, Senok A, Abou Tayoun A, Hamoudi R, Alsheikh-Ali A, et al. Regulation of angiotensin converting enzyme 2 (ACE2) in obesity: implications for COVID-19. bioRxiv. 2020.

40. Anti-angiogenic Targets: Angiopoietin and Angiopoietin Receptors. 
41. Effect of Azithromycin sequential therapy on T cell subsets, Lactate dehydrogenase, cytokine levels and prognosis in children with mycoplasma Pneumonia. Chinese journal of the Frontiers of Medical Science. 2018;10(9):113-114.

\section{Tables}

Table 1: Section 1: Case Series of Severe Patients With Different Comorbidities in 2020

The first and second cases were given Azithromycin in two divided doses. Pantoprazole was not given to them initially. It was given after 7 days of therapy.

In cases where intravenous infusion Ceftriaxone $2 \mathrm{~g}$ was given, Serum Bilirubin levels were monitored. 


\begin{tabular}{|c|c|c|c|c|c|c|}
\hline Case & $\begin{array}{l}\text { Age } \\
\text { (yrs)/ } \\
\text { Gender }\end{array}$ & $\begin{array}{l}\text { Chief } \\
\text { complaints }\end{array}$ & Co-morbidities & Hospitalization & Diagnosis & $\begin{array}{l}\text { Medications } \\
\text { recommended }\end{array}$ \\
\hline \multirow[t]{2}{*}{1} & \multirow[t]{2}{*}{$49 / \mathrm{M}$} & \multirow[t]{2}{*}{$\begin{array}{l}\text { Fever, } \\
\text { shortness of } \\
\text { breath, } \\
\text { oxygen } \\
\text { saturation } \\
\text { fluctuations }\end{array}$} & \multirow[t]{2}{*}{$\begin{array}{l}\text { Hypertensive, } \\
\text { hyperlipidemia, } \\
\text { obesity }\end{array}$} & \multirow[t]{2}{*}{ Yes } & \multirow[t]{2}{*}{$\begin{array}{l}\text { Obesity and } \\
\text { hypertension with } \\
\text { COVID induced } \\
\text { Cytokine storm } \\
\text { syndrome }\end{array}$} & $\begin{array}{l}\text { Azithromycin } \\
500 \mathrm{mg} \mathrm{BD} \text {, } \\
\text { Itraconazole } \\
200 \mathrm{mg} \mathrm{BD}, \\
\text { Pentoxifylline } \\
400 \mathrm{mg}, \\
\text { Dexamethasone } \\
4 \mathrm{mg} \text {, }\end{array}$ \\
\hline & & & & & & Telmisartan, \\
\hline \multirow[t]{2}{*}{2} & \multirow[t]{2}{*}{$46 / F$} & \multirow[t]{2}{*}{$\begin{array}{l}\text { Fever, UTI, } \\
\text { diarrhea, } \\
\text { nausea, } \\
\text { Vomiting }\end{array}$} & \multirow[t]{2}{*}{$\begin{array}{l}\text { Obesity, Previous } \\
\text { history of } \\
\text { metabolic } \\
\text { acidosis }\end{array}$} & \multirow[t]{2}{*}{ Yes } & \multirow[t]{2}{*}{$\begin{array}{l}\text { COVID induced } \\
\text { Diabetes with } \\
\text { Metabolic Acidosis }\end{array}$} & $\begin{array}{l}\text { Azithromycin } \\
500 \mathrm{mg} \mathrm{BD} \text {, } \\
\text { Itraconazole } \\
200 \mathrm{mg} \mathrm{BD}, \\
\text { Pentoxifylline } \\
400 \mathrm{mg}, \\
\text { Dexamethasone } \\
4 \mathrm{mg}\end{array}$ \\
\hline & & & & & & $\begin{array}{l}\text { Intravenous } \\
\text { Ceftriaxone } 2 \mathrm{~g} \\
\text { BB }\end{array}$ \\
\hline \multirow[t]{3}{*}{3} & \multirow[t]{3}{*}{$49 / F$} & \multirow{3}{*}{$\begin{array}{l}\text { Vertigo, } \\
\text { oxygen } \\
\text { saturation } \\
\text { fluctuations, } \\
\text { fatigue and } \\
\text { cough }\end{array}$} & \multirow{3}{*}{$\begin{array}{l}\text { Diabetes, } \\
\text { obesity, treated } \\
\text { breast } \\
\text { carcinoma, } \\
\text { Inflammatory } \\
\text { Bowel Syndrome }\end{array}$} & \multirow[t]{3}{*}{ No } & \multirow{3}{*}{$\begin{array}{l}\text { Carcinoma breast } \\
\text { with inflammatory } \\
\text { bowel disease with } \\
\text { COVID induced } \\
\text { Diabetes. }\end{array}$} & $\begin{array}{l}\text { Pantoprazole } \\
40 \text { mg BD }\end{array}$ \\
\hline & & & & & & $\begin{array}{l}\text { Azithromycin } \\
1000 \mathrm{mg} \mathrm{OD,} \\
\text { Itraconazole } \\
200 \mathrm{mg} \mathrm{BD}, \\
\text { Pentoxifylline } \\
400 \mathrm{mg}, \\
\text { Dexamethasone } \\
4 \mathrm{mg}\end{array}$ \\
\hline & & & & & & Metformin, \\
\hline \multirow[t]{3}{*}{4} & \multirow[t]{3}{*}{$83 / \mathrm{M}$} & \multirow{3}{*}{$\begin{array}{l}\text { Moderate } \\
\text { Fever, dry } \\
\text { cough, } \\
\text { Fatigue, } \\
\text { restlessness, } \\
\text { confusion }\end{array}$} & \multirow{3}{*}{$\begin{array}{l}\text { Hypertension, } \\
\text { Acute Coronary } \\
\text { Syndrome, deep } \\
\text { venous } \\
\text { thrombosis }\end{array}$} & \multirow[t]{3}{*}{ No } & \multirow[t]{3}{*}{$\begin{array}{l}\text { Acute Coronary } \\
\text { Syndrome with covid } \\
\text { induced Pneumonia. }\end{array}$} & $\begin{array}{l}\text { Pantoprazole } \\
40 \text { mg BD }\end{array}$ \\
\hline & & & & & & $\begin{array}{l}\text { Azithromycin } \\
1000 \mathrm{mg} \mathrm{OD} \\
\text { Itraconazole } \\
200 \mathrm{mg} \mathrm{BD}, \\
\text { Pentoxifylline } \\
400 \mathrm{mg}, \\
\text { Dexamethasone } \\
4 \mathrm{mg}\end{array}$ \\
\hline & & & & & & $\begin{array}{l}\text { Aspirin } 75 \mathrm{mg}, \\
\text { Apixaban } \\
2.5 \mathrm{mg}\end{array}$ \\
\hline \multirow[t]{3}{*}{5} & \multirow[t]{3}{*}{$44 / \mathrm{M}$} & $\begin{array}{l}\text { High grade } \\
\text { fever, } \\
\text { Tachycardia, }\end{array}$ & \multirow[t]{3}{*}{ No } & \multirow[t]{3}{*}{ No } & \multirow{3}{*}{$\begin{array}{l}\text { Hypertensive with } \\
\text { Hypercholesterolemia } \\
\text { with obesity with } \\
\text { hypertriglyceridemia }\end{array}$} & $\begin{array}{l}\text { Pantoprazle } 40 \\
\text { mg BD }\end{array}$ \\
\hline & & Fatigue & & & & $\begin{array}{l}\text { Azithromycin } \\
\text { 1000mg OD }\end{array}$ \\
\hline & & $\begin{array}{l}\text { Shortness of } \\
\text { bresth }\end{array}$ & & & & $\begin{array}{l}\text { Pentoxifylline } \\
\text { 400mg, } \\
\text { Dexamethasone } \\
4 \mathrm{mg},\end{array}$ \\
\hline
\end{tabular}


Table 2: Section 1: Laboratory findings (Borderline/mild/low/moderate/high/very high)

The references were different from each laboratory, hence the grading was based on the levels of reference levels

\begin{tabular}{|c|c|c|c|c|c|c|c|c|}
\hline Case & $\begin{array}{l}\text { Serum } \\
\text { ferritin/ } \\
\text { IL- } 6\end{array}$ & LDH & $\begin{array}{l}\text { D } \\
\text { dimer }\end{array}$ & CRP & ESR & LIPIDS & FBS & CBC/LFT/RFT/CPK/Electrolytes \\
\hline 1 & $\begin{array}{l}\text { Very high } \\
\text { /High }\end{array}$ & $\begin{array}{l}\text { Very } \\
\text { HIGH }\end{array}$ & $\begin{array}{l}\text { Very } \\
\text { High }\end{array}$ & $\begin{array}{l}\text { Very } \\
\text { High }\end{array}$ & high & $\begin{array}{l}\text { High } \\
\text { Cholesterol } \\
\text { and } \\
\text { Triglycerides }\end{array}$ & Normal & $\begin{array}{l}\text { Low lymphocytes, low } \\
\text { Neturophils, High TLC count, } \\
\text { High CPK } \\
\text { High RBC count } \\
\text { Low sodium amd potassium } \\
\text { and chloride }\end{array}$ \\
\hline 2 & Normal & $\mathrm{HIGH}$ & Normal & high & high & $\begin{array}{l}\text { High } \\
\text { Triglycerides } \\
\text { and } \\
\text { Cholesterol }\end{array}$ & High & $\begin{array}{l}\text { High lymphocytes } \\
\text { Low Eosinophils } \\
\text { High Platelets } \\
\text { High RBC count } \\
\text { High Chlorides } \\
\text { High Magnesium }\end{array}$ \\
\hline 3 & Normal & High & High & High & NA & Normal & $\begin{array}{l}\text { Very } \\
\text { High }\end{array}$ & $\begin{array}{l}\text { Lymphocytosis } \\
\text { Neutropenia } \\
\text { Platelets high } \\
\text { High RBC count }\end{array}$ \\
\hline 4 & $\begin{array}{l}\text { High/Very } \\
\text { High }\end{array}$ & $\begin{array}{l}\text { Very } \\
\text { High }\end{array}$ & High & $\begin{array}{l}\text { Very } \\
\text { High }\end{array}$ & High & $\begin{array}{l}\text { Very high } \\
\text { Low HDL }\end{array}$ & Mild & $\begin{array}{l}\text { Lymphopenia } \\
\text { Neutrophilia } \\
\text { High RBC count } \\
\text { Low sodium, Potassium } \\
\text { Moderate Serum creatinine } \\
\text { High BUN leevel }\end{array}$ \\
\hline 5 & High & $\begin{array}{l}\text { Very } \\
\text { High }\end{array}$ & High & High & High & High & Normal & $\begin{array}{l}\text { Lymphocytosis } \\
\text { Neutropenia } \\
\text { High RBC count }\end{array}$ \\
\hline
\end{tabular}


Table 3: Laboratory/ Blood Parameters Of Severe Covid 19 Patients During The Second Wave Of Pandemic(2021)

\begin{tabular}{|c|c|c|c|c|c|c|c|c|}
\hline \multirow{2}{*}{$\begin{array}{l}\text { Patient Ref } \\
\text { Patient 1: 50yr/F }\end{array}$} & \multicolumn{2}{|c|}{ Test 1} & \multicolumn{2}{|c|}{ Test 2} & \multicolumn{2}{|c|}{ Test 3} & \multicolumn{2}{|c|}{ Test 4} \\
\hline & \multicolumn{2}{|c|}{$19 / 04 / 2021$} & \multicolumn{2}{|c|}{$22 / 04 / 2021$} & \multicolumn{2}{|c|}{$24 / 04 / 2021$} & \multicolumn{2}{|c|}{$01 / 05 / 2021$} \\
\hline & CRP & 3.26 & CRP & 25.63 & CRP & 20.70 & CRP & 64.10 \\
\hline & $\mathrm{LDH}$ & & $\mathrm{LDH}$ & & LDH & 231 & LDH & 294 \\
\hline & \multicolumn{2}{|c|}{ D Dimer 0.31} & \multicolumn{2}{|c|}{ D Dimer 0.39} & \multicolumn{2}{|c|}{ D Dimer 0.36} & \multicolumn{2}{|c|}{ D Dimer } \\
\hline & \multicolumn{2}{|l|}{ IL-6 } & IL-6 & 50.1 & \multicolumn{2}{|l|}{ IL-6 } & \multicolumn{2}{|l|}{ IL-6 } \\
\hline \multirow[t]{5}{*}{ Patient 2: 48yr/F } & \multicolumn{2}{|c|}{$15 / 04 / 2021$} & \multicolumn{2}{|c|}{$18 / 04 / 2021$} & \multicolumn{2}{|c|}{$21 / 04 / 2021$} & & \\
\hline & CRP & 10.92 & CRP & 13.69 & CRP & 8.56 & & \\
\hline & \multirow{3}{*}{\multicolumn{2}{|c|}{ D Dimer 22}} & \multicolumn{2}{|c|}{ D Dimer 0.57} & & & & \\
\hline & & & \multicolumn{2}{|c|}{ Lymphocyte 0.73} & \multirow{2}{*}{\multicolumn{2}{|c|}{ Lymphocyte 0.6}} & & \\
\hline & & & Fact & $<150$ & & & & \\
\hline \multirow[t]{5}{*}{ Patient 3: 81yr/M } & \multicolumn{2}{|c|}{$14 / 04 / 2021$} & \multicolumn{2}{|c|}{$16 / 04 / 2021$} & \multicolumn{2}{|c|}{$19 / 04 / 2021$} & \multicolumn{2}{|c|}{$24 / 04 / 2021$} \\
\hline & CRP & 43.42 & CRP & 26.15 & CRP & 5.22 & CRP & 2.19 \\
\hline & LDH & 228 & $\mathrm{LDH}$ & 216 & LDH & 183 & LDH & 189 \\
\hline & \multicolumn{2}{|c|}{ D Dimer 1.48} & \multicolumn{2}{|c|}{ D Dimer 1.20} & \multicolumn{2}{|c|}{ D Dimer 0.87} & \multicolumn{2}{|c|}{ D Dimer 0.67} \\
\hline & IL-6 & 18.3 & IL-6 & 1.70 & IL-6 & 6.38 & IL-6 & \\
\hline
\end{tabular}

Table 4 is available in the Supplementary Files section

Figures 


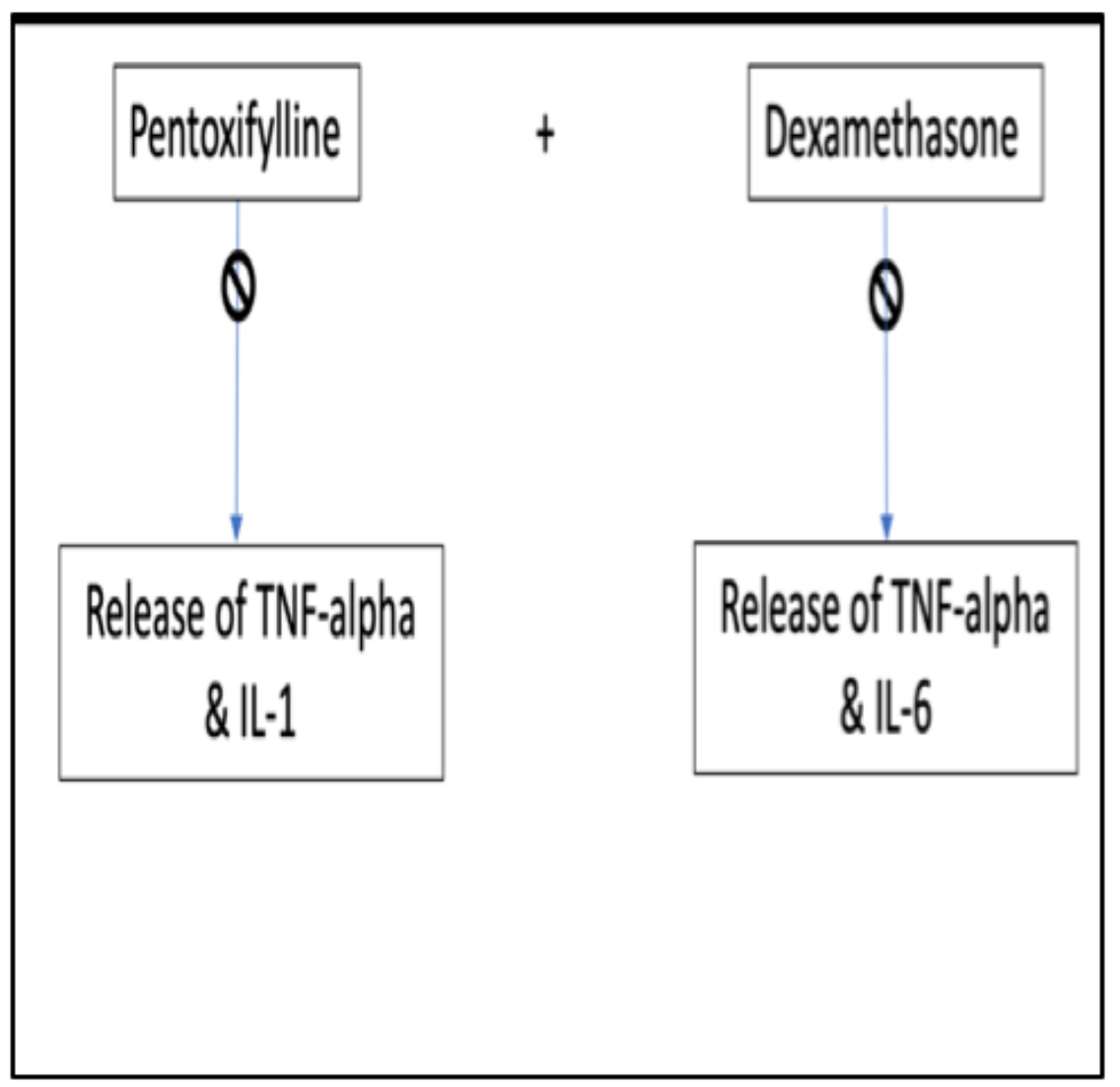

Figure 1

Effect of Pentoxifylline and Dexamethasone on inflammatory markers. 


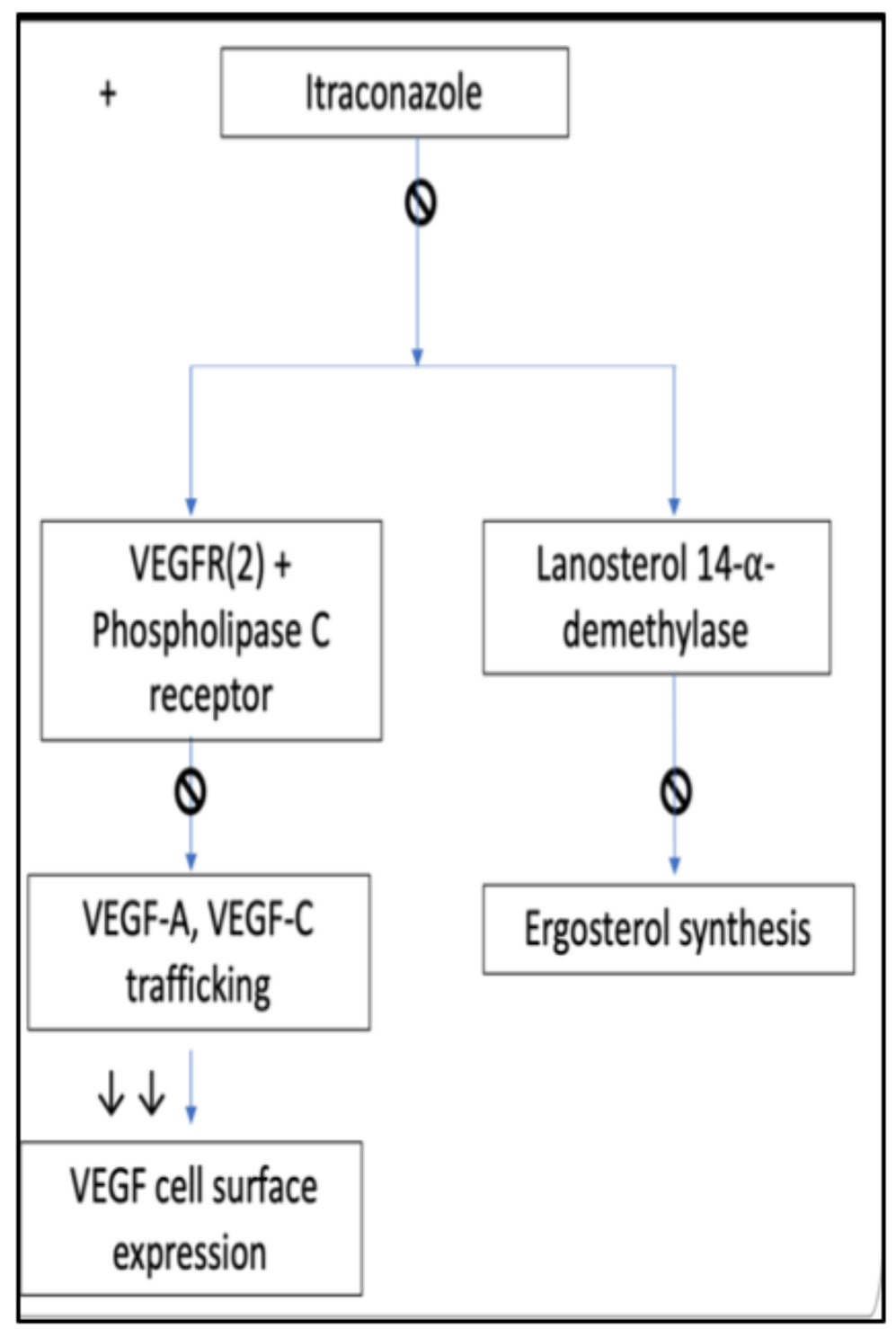

Figure 2

Role of Itraconazole in lowering the Cholesterol and LDL -C critical for host entry of the virus and its further replication. Its effect as a potent VEGF A inhibitor 


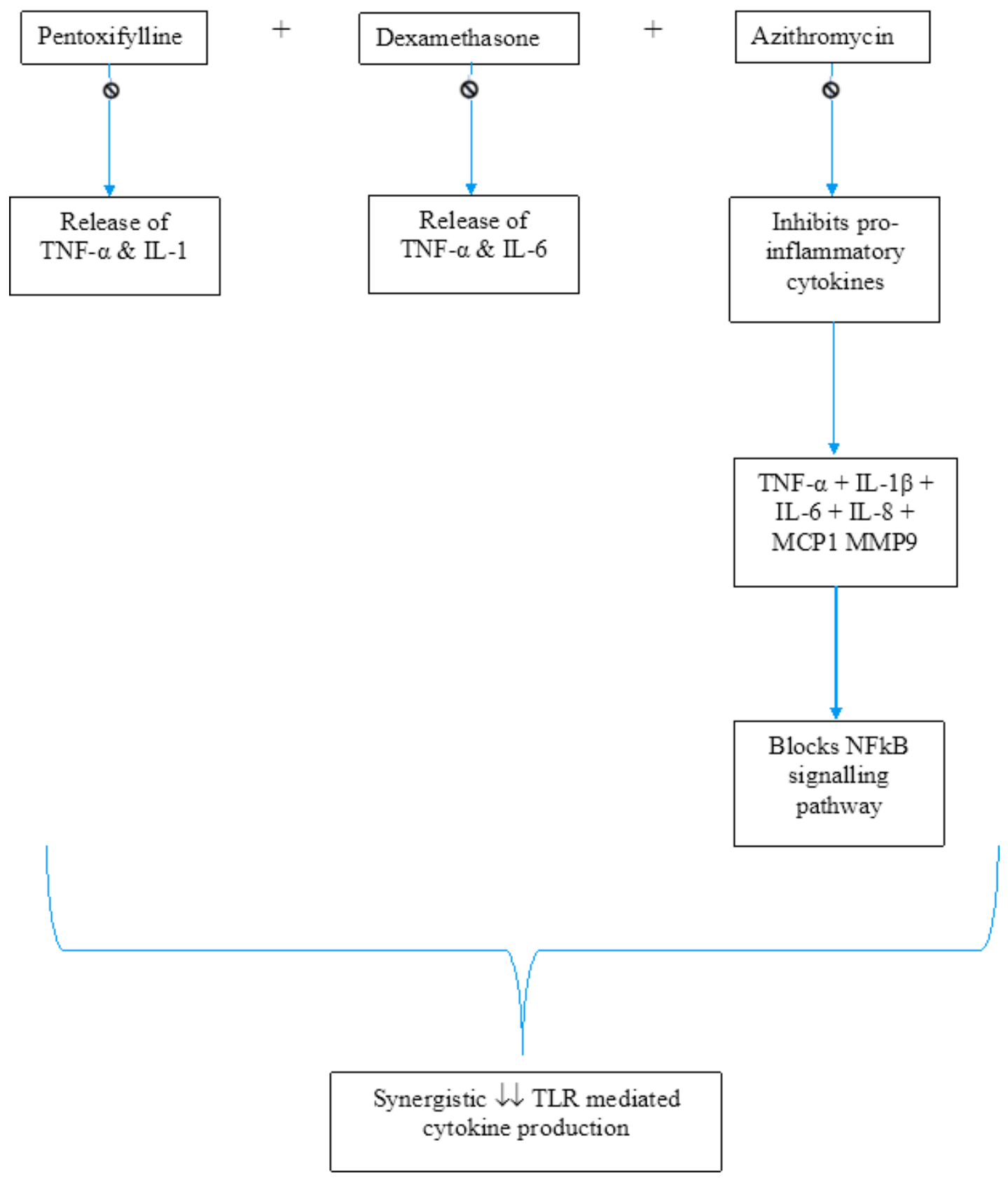

Figure 3

Drugs responsible for Inhibition of Toll like receptor immunity responsible for severity and cytokine storm in COVID 19 .

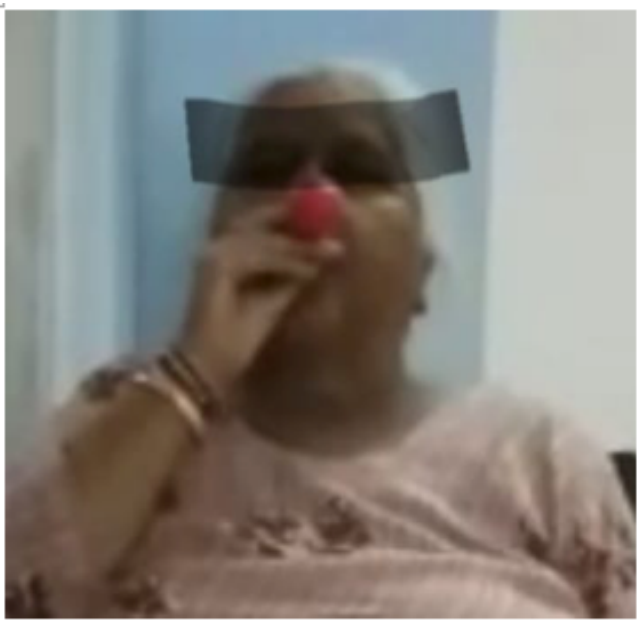




\section{Figure 4}

DAY 3 OF TREATMENT, SHE HAD NPO FEVER, HER LUNG FIBROSIS GOT BETTER.

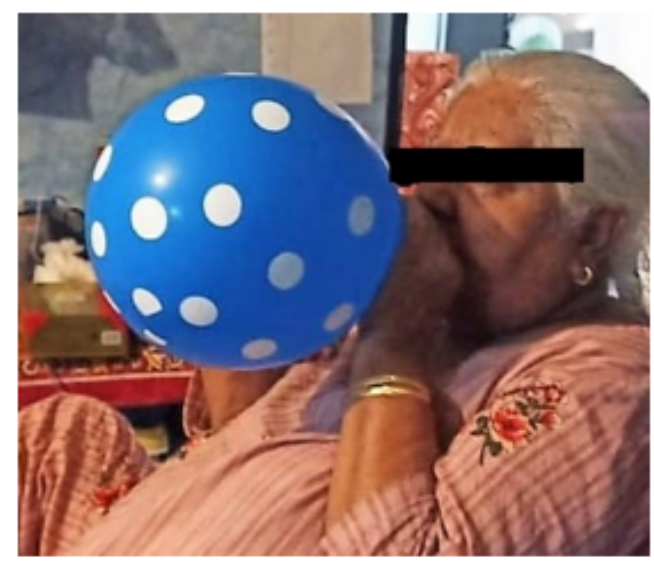

\section{Figure 5}

Day 10 of treatment after giving intravenous Ceftriaxone $2 \mathrm{~g}$, her serum ferritin came to normal and other lab parameters got normal. Her sugar levels were also under control.

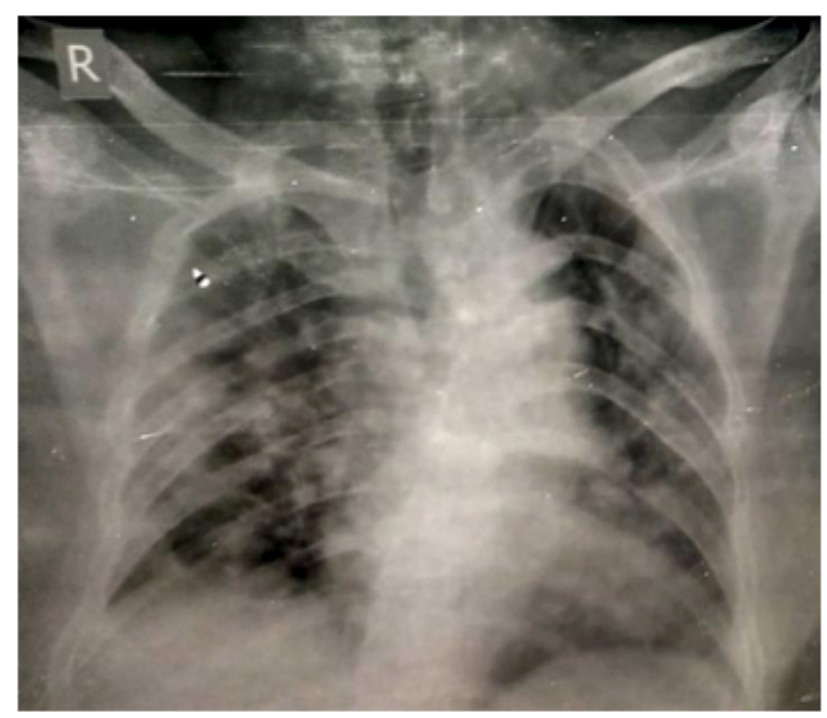

\section{Figure 6}

Case-1 A 44-year-old obese male with hypertriglyceridemia, hypercholesterolemia, hypertension developed Cytokine Storm Syndrome. After Treatment. After hospitalization, showing multiple lung opacities on the 12th day after stopping Azithromycin $500 \mathrm{mg}$ twice a day with Pentoxifylline $400 \mathrm{mg}$. There were no reports for comparison. 


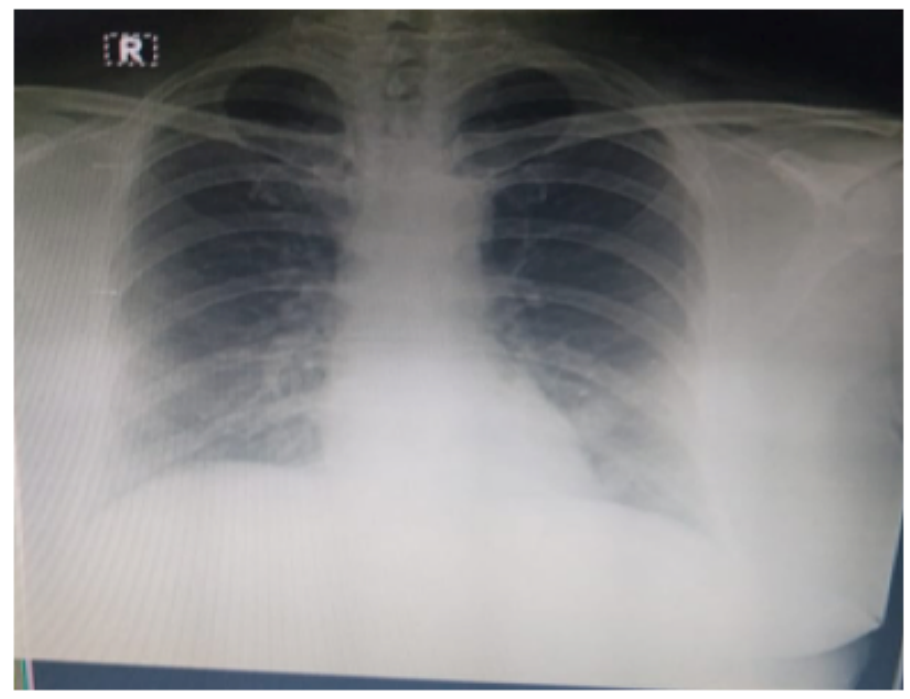

\section{Figure 7}

Case-2 After treatment. Case 2 : Shows basal lung involvement, opacities after treatment with Azithromycin 500 mg twice a day and Dexamethasone $2 \mathrm{mg}$. Pentoxifylline $400 \mathrm{mg}$ was started 2 days before the hospitalization and Xray was taken.

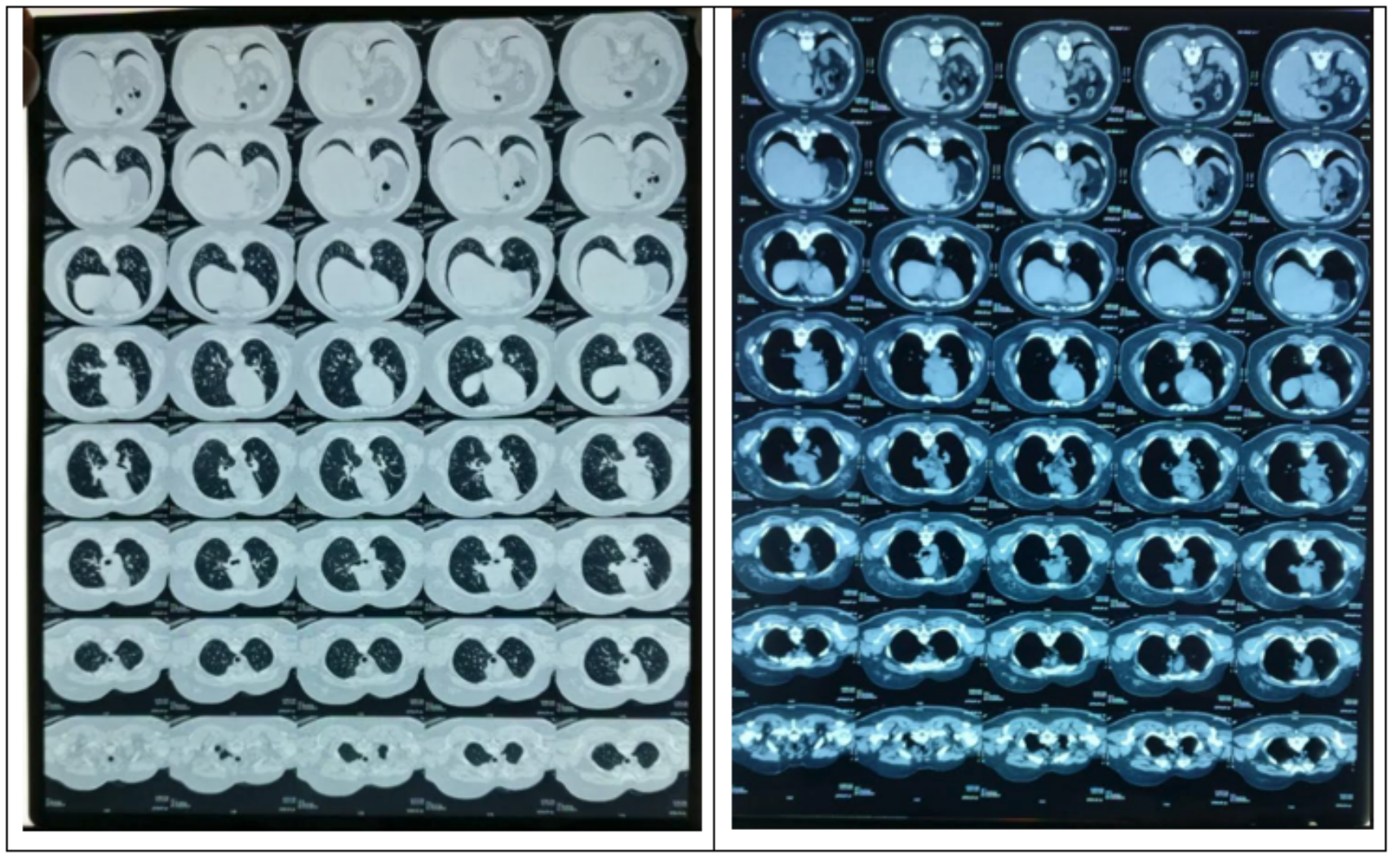

Figure 8

Case-3 HRCT of 49-year-old morbidly obese female with Crohn's Disease and previous history of dual ovarian-breast cancer. CT Severity score: $9 / 25$ This CT severity score was calculated after 9 days of treatment. The patient was having restlessness but got resolved in a few days. 


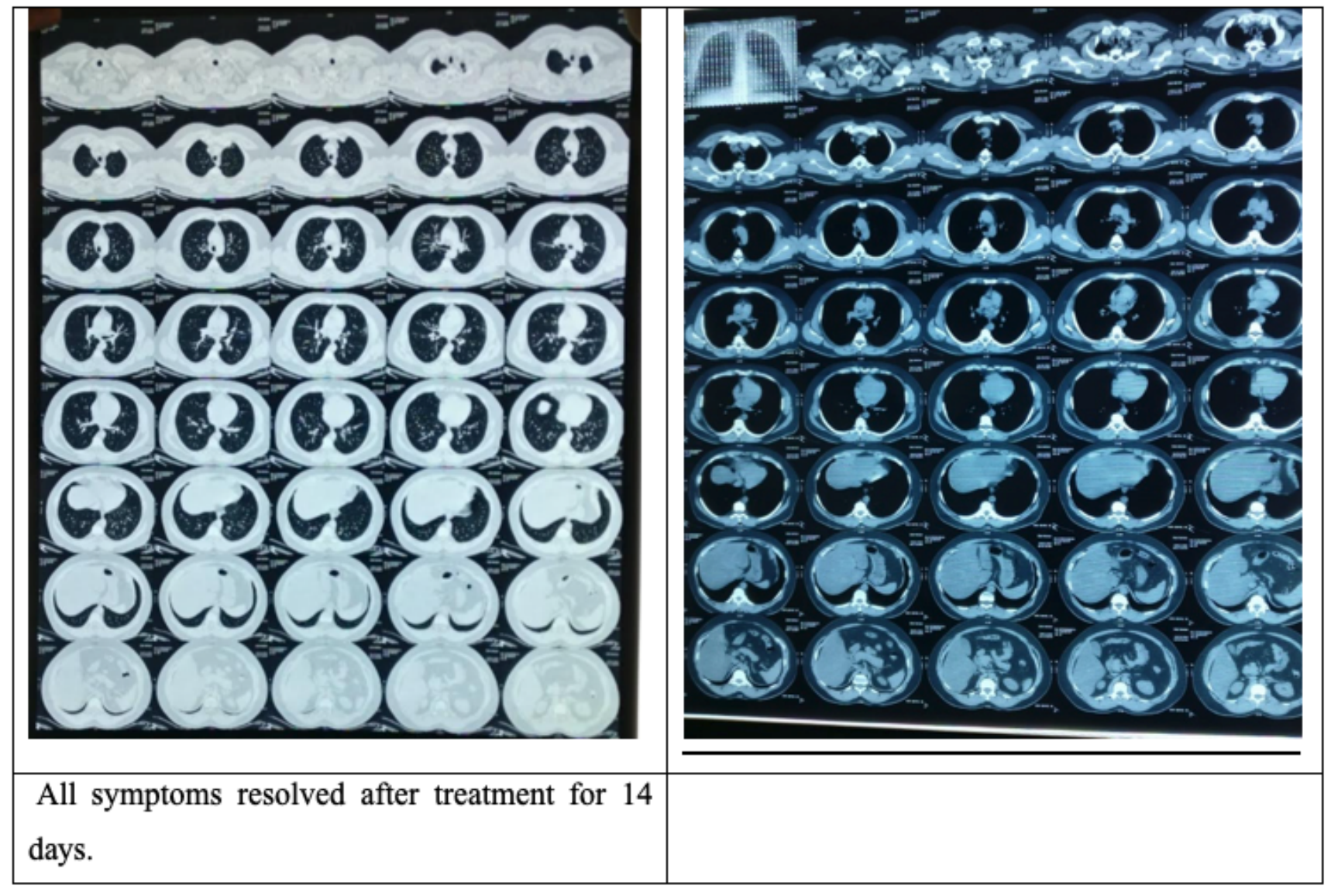

\section{Figure 9}

Case-5 A 44 year old obese male with high Lipids, cough, high grade fever, loss of taste and smell and CT Severity score: $4 / 25$ after 10 days of treatment

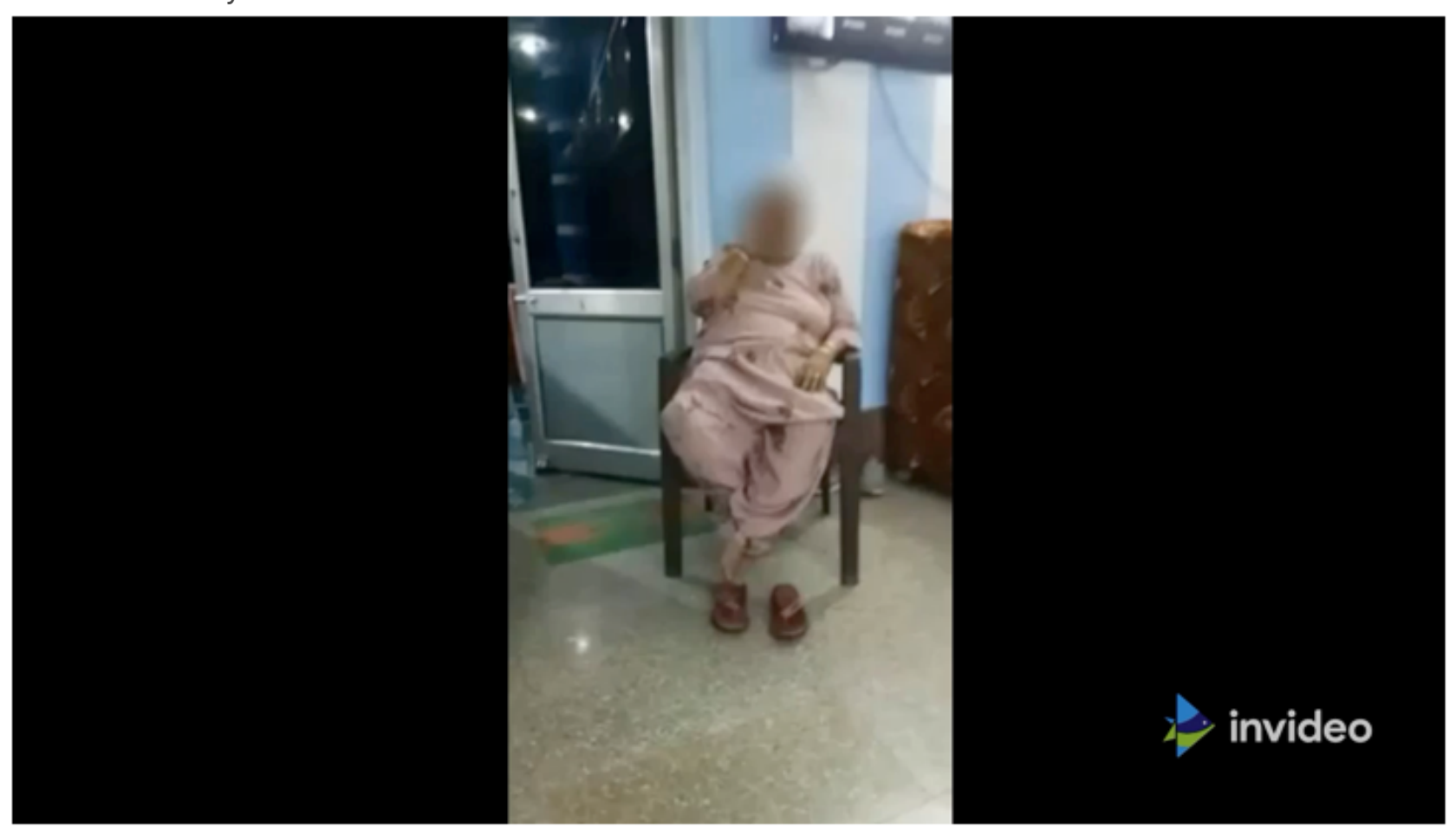

Figure 10 
Day 3 of treatment with the combination therapy. The patient culd walk only for 3 minutes. Her inspiration was also hindered and there was less fatigue and no fever.

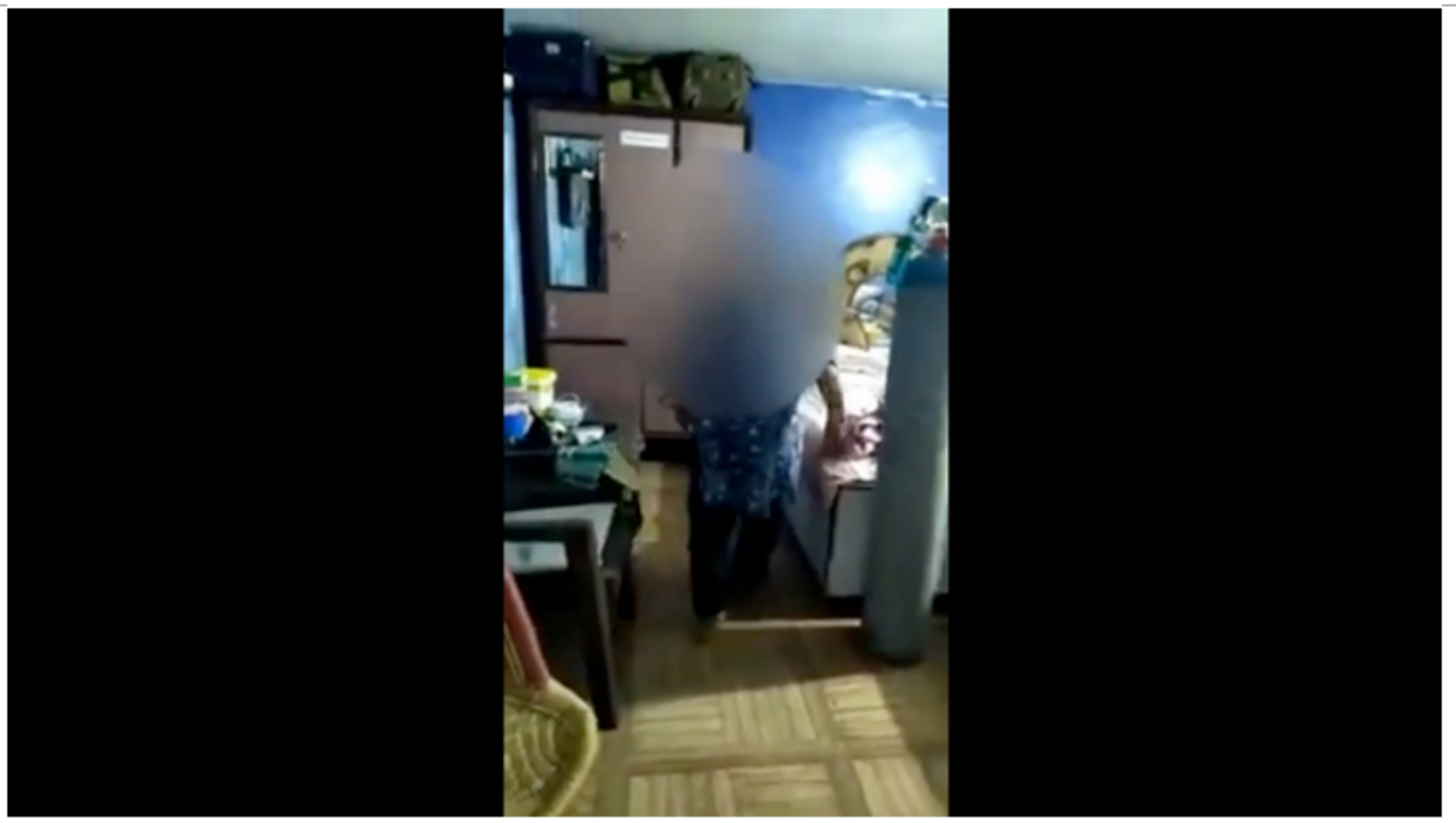

\section{Figure 11}

After 7 days of therapy, patient is able to walk for 6 minutes with a $4 \mathrm{~mm}$ drop in oxygen saturation. Her Pulse rate which was higher Iso settled at 85.

\section{Supplementary Files}

This is a list of supplementary files associated with this preprint. Click to download.

- image.jpg

- Video1mute.mp4

- Video1mute.mp4 